\title{
The interactions between habitat, sex, biomass and leaf traits of different willow (Salix) genotypes
}

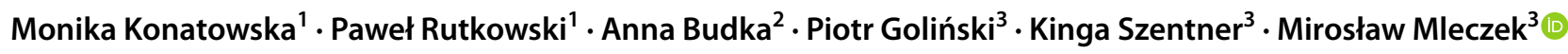

Received: 3 November 2020 / Revised: 17 January 2021 / Accepted: 5 February 2021 / Published online: 20 February 2021

(c) The Author(s) 2021

\begin{abstract}
Knowledge of the impacts of sex on plant mortality and biomass production has scientific and practical importance. In the case of willows, we know relatively little about such effects. The main objective of this study was to evaluate whether the sex of individuals of different willow species determines their biomass and mortality. An additional goal was to determine whether the secondary sex characteristics, such as leaf traits, depend on sex. The experiment was conducted from 2011 to 2014 with 8100 plants comprising 150 willow genotypes, including 8 species, 16 interspecies hybrids, cultivars, and specimens differentiated by sex. Statistical analysis of the leaf traits revealed their relationship to sex. On average, male specimens have longer and wider leaves. They also have longer petioles. Males of the studied Salix genotypes were characterized by higher biomass and showed a greater survival rate than females but only under better site conditions; when the site conditions were poorer, males had higher mortality than females.
\end{abstract}

\section{Article Highlights}

- Effective rock phosphate (RP) solubilization by Bacillus thuringenesis $P_{0} B_{11}$, Lysinobaccillus fusiformis $P_{0} B_{28}$, and Aspergillus aculeatus $P_{0} F_{3}$ isolated from Mahanadi estuary of Odisha, India.

- First report of RP solubilization by L. fusiformis $P_{0} B_{28}$. First report of in vitro stearic acid production during RP solubilization.

Keywords Biomass $\cdot$ Mortality $\cdot$ Salix $\cdot$ Sexual dimorphism $\cdot$ Willows

Mirosław Mleczek

miroslaw.mleczek@up.poznan.pl

1 Department of Forest Sites and Ecology, Poznań University of Life Sciences, Poznań, Poland

2 Department of Mathematical and Statistical Methods, Poznań University of Life Sciences, Poznań, Poland

3 Department of Chemistry, Poznań University of Life Sciences, Poznań, Poland
- Organic acids were the major mechanism for RP solubilization and responsible for morphological and mineralogical changes confirmed by SEM, XRD and FTIR, respectively.

\section{Introduction}

Willows (genus Salix) have a very significant utility and play an important environmental role. Their importance in medicine (e.g., Uehleke et al. 2013; Desborough and Keeling 2017), as a source of renewable energy (Lipiński and Żejmo 2012; Bakšienè and Titova 2018), in the basketry and furniture industries (Bhat et al. 2017), phytoremediation (Goliński et al. 2015; Mleczek et al. 2017, 2018) and many other fields is well known. Salix species are components of such important Natura 2000 habitats as 2170 (dunes with Salix repens ssp. argentea), 3210 (Fennoscandian natural rivers), 4080 (subarctic Salix spp. scrub), 6450 (northern boreal alluvial meadows), 91E0 (alluvial 
forests), 92A0 (Salix alba and Populus alba galleries) and 92B0 (riparian formations on intermittent Mediterranean water courses) (EC 2013). Willows are also a source of pollen and nectar for pollinating insects (Ostaff et al. 2015). However, despite such a wide field of interest in numerous studies devoted to willows, the fact that willows are dioecious and that the results of investigations may depend on the sex of the tested specimens is often ignored (Hytönen 1995; Larsson 1998; Labrecque and Teodorescu 2003; Nordh and Verwijst 2004; Smart et al. 2005).

It is well-known-almost a truism-that differences between sexes are common in nature and determine primary and secondary sex characters (Barrett and Hough 2013). Sexual dimorphism (SD) is observed in many organisms, such as humans, cervids (Geist and Bayer 2009), birds (Owens and Hartley 1998), spiders (Foellmer and Moya-Laraño 2007; Inkpen and Foellmer 2010) and other animals, while SD in plants is much less widely appreciated (Geber et al. 1999). Meanwhile, focusing attention on the sex of plant specimens and the effects of the differences between the sexes may have significant ecological and practical significance. This has been demonstrated, among others, on an example of Cannabis sativa and Spinacia oleracea (Lloyd and Webb 1977), Nyssa aquatica (Shea et al. 1993), Phoenix dactylifera, Silene latifolia, Zea mays and Ceratopteris richardii (Juarez and Banks 1998), Corema album (Álvarez-Cansino et al. 2010), Mercurialis annua (Hesse and Pannell, 2011), Phoenix dactylifera (Intha and Chaiprasart, 2018) and Ambrosia artemisiifolia (Nakahara et al. 2018), but there are few such works on willows (Mirski 2014; Yang et al. 2020).

Current knowledge allows us to conclude that males tend to be larger than females in relatively large species, while females tend to be the larger in relatively small species (Abouheif and Fairbairn, 1997; Fairbairn 1997; Colwell 2000; Obeso 2002), this is known as Rensch's rule (Rensch, 1960). It is also considered that dioecious male individuals usually produce higher biomass than those that are not dioecious (Galambosi et al. 2009), but biomass production may depend on site conditions. As Tognetti (2012) summarized, according to Dawson and Bliss (1989), females are more common in high-resource and males in low-resource microsites. Similar observations were noted by Bierzychudek and Eckhart (1988), Mercer and Eppley (2010) and Barrett and Hough (2013).

Science has attempted to explain why females and males display different advantages under different site conditions but there remain many unanswered questions. Therefore, the main objective of this study was to test whether the sex of specimens of different willow species affected their biomass and mortality. An additional goal was to determine whether secondary sex characteristics, such as leaf traits, depend on the sex of an individual.

\section{Materials and methods}

The described project is based on the Poznań University of Life Sciences Willow Collection, which is located in different parts of Poland. The collection dates back to the 1960s and now comprises 150 genotypes. Their taxonomy was verified by Professor Jerzy Zieliński of the Institute of Dendrology, Polish Academy of Sciences.

\section{Study area}

All genotypes of willows included in the Willow Collection were randomly planted in 2011, with replication across 34 experimental plots at 6 locations. The research areas described in this paper comprise three locations named: S-43, S-52 and S-85. The coordinates of the centers of these areas are S-43-51 $13^{\prime} 4^{\prime \prime} \mathrm{N} ; 18^{\circ} 02^{\prime} 19^{\prime \prime} \mathrm{E}$ (Fig. 1a),

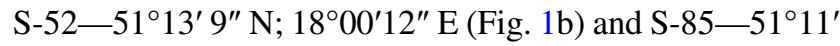
$33^{\prime \prime} \mathrm{N} ; 18^{\circ} 04^{\prime} 47^{\prime \prime}$ E (Fig. 1c).

Research area S-43 comprises four experimental plots (Fig. 1a), S-52-six plots (Fig. 1b), and S-85-eight plots (Fig. 1c). Figure 1d shows an enlargement of the S-43 research area. In plots No. 1 and No. 4, the rows were oriented to the NE-SW direction. At plots No. 2 and No. 3, they were oriented to the NW-SE direction. Figure 1e, f show the enlargement of the rows at plots Nos. 1 and 3, where all plants were planted in rows at a distance of $0.5 \mathrm{~m}$ between cuttings and $1.5 \mathrm{~m}$ between rows (as in all the other plots). The distribution of genotypes in each plot is random. In each plot, each taxon is represented by three plants (Fig. 1e, f; red, yellow, green and blue dots). Each plant is mapped and the location and features of each plant were noted in the ArcGIS program (Fig. 1g).

The maximal distance between these three areas is $6.2 \mathrm{~km}$, hence macroclimatic conditions are similar [for Wieluń meteorological station $\left(51^{\circ} 12^{\prime} 39^{\prime \prime} \mathrm{N} ; 18^{\circ} 33^{\prime} 25^{\prime \prime} \mathrm{E}\right.$; altitude: $201 \mathrm{~m}$ a.s.l.), for the period 1987-2014 the average annual temperature was $8.8{ }^{\circ} \mathrm{C}$ and the average annual precipitation was $564 \mathrm{~mm}$ (public data)]. Research areas S-43, S-52 and S-85 are flat so the relief of all locations is identical. Therefore, climatic and relief interactions were excluded from the sex-biomass and sex-mortality analyses.

In 2010, the year before willow planting, a basic soil description was performed which included soil type, its granulometric composition [determined using sedimentation methods (PN-R-04032 1998; PN-R-04033 1998), pH (PN-ISO 10390. 1997) and the water regime. The soil features, such as soil type, type of sediment and water availability were described on the basis of the pit soil, 
Fig. 1 a-c Experimental design of plots at the research areas: S-43 (a), S-52 (b), S-85 (c); the numbers on Figs. 1a-c mean the number of replicated experimental plots in given location; d the enlargement of the S-43 research area with visible rows of planted willows; $\mathbf{e}$ and $\mathbf{f}$ the enlargement of the rows at plots; red, yellow, green and blue dots show the distribution of genotypes in each row (3 plants by each taxon); $\mathbf{g}$ an example of a description of each plant made in the ArcGIS program

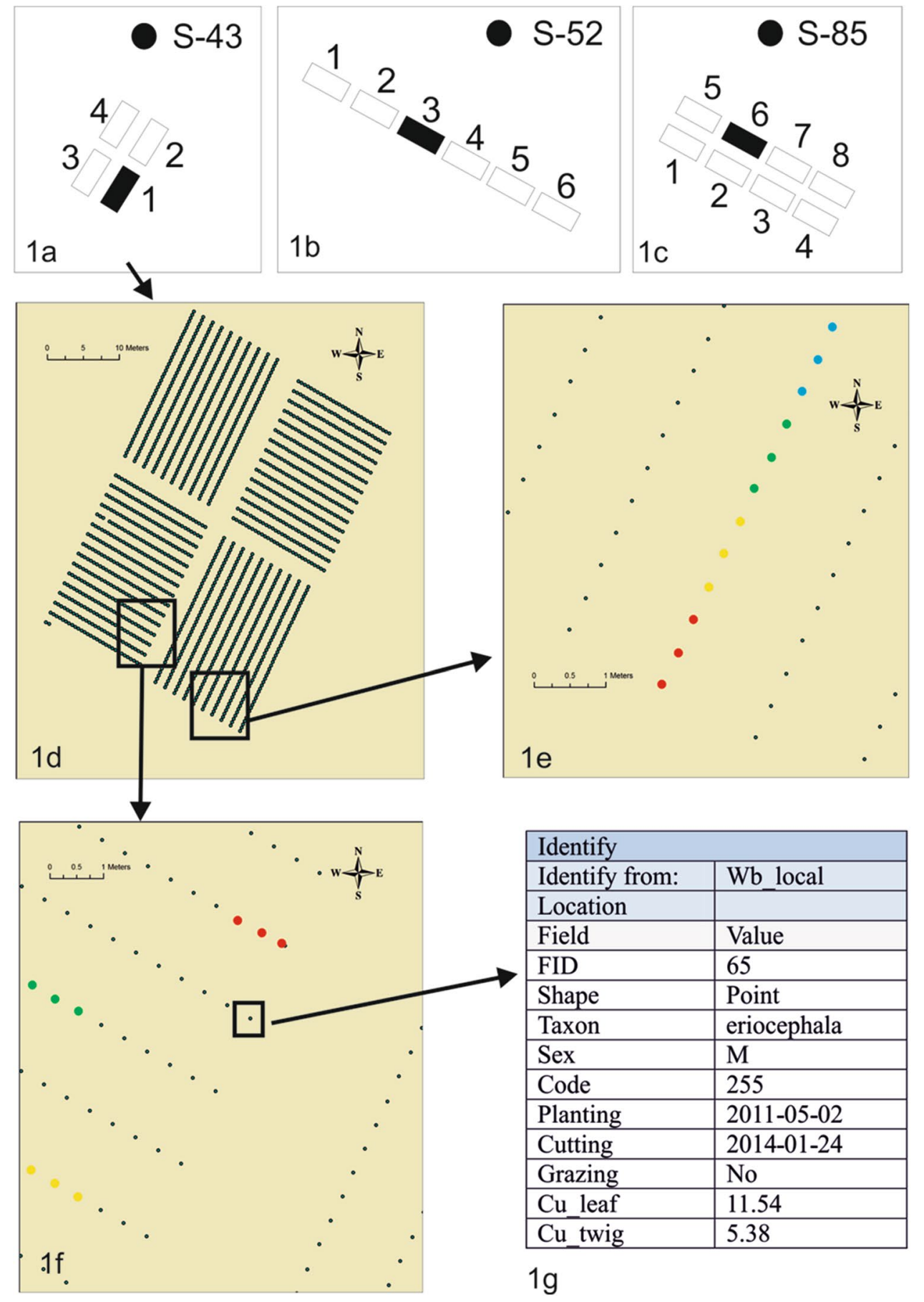

dug by hand in the middle of each research area to a depth of $1.5 \mathrm{~m}$. At two of the three locations -at depths of 0.95 and $1.50 \mathrm{~m}$-the groundwater table was found (S-85 and S-43, respectively). Additionally, in 2011 soil samples were collected with a soil sampling tube from a depth of $0.0-0.25 \mathrm{~m}$. The samples were then placed in polypropylene containers and transported to the laboratory, where the total content of organic carbon according to the Polish standard (PN-ISO 14235 2003) and nitrogen according to the Kjeldahl method (PN-ISO 11261 2002) were analyzed.

\section{Characteristics of plant material and experimental design}

The Poznań University of Life Sciences Willow Collection comprises 150 genotypes, including species, natural 
Table 1 Summary of shoot mass in all tested genotypes and the results of Tukey's test

\begin{tabular}{|c|c|c|c|c|c|c|c|}
\hline \multirow[t]{3}{*}{ No } & \multirow[t]{3}{*}{ Name of taxon } & \multirow[t]{3}{*}{ Sex code } & \multicolumn{3}{|c|}{ Location } & \multirow[t]{3}{*}{ Average } & \multirow[t]{3}{*}{ Tukey's test } \\
\hline & & & S 43 & S 52 & S 85 & & \\
\hline & & & \multicolumn{3}{|c|}{ Mass (kg) } & & \\
\hline 1 & Salix purpurea $\mathrm{L} . \times$ triandra $\mathrm{L} . \times$ viminalis $\mathrm{L}$. ' 15 ' & $\mathrm{F}$ & 14.5 & 12 & 8 & 11.5 & a \\
\hline 2 & S. purpurea $\times$ triandra. $\times$ viminalis ' 46 ' & $\mathrm{F}$ & 5 & 9.5 & 12.5 & 9 & $a b$ \\
\hline 3 & S. $\times$ smithiana Willd. ' 5 ' & M & 10.5 & 3 & 11.5 & 8.33 & $a b c$ \\
\hline 4 & S. $\times$ smithiana ' 1 ' & $\mathrm{F}$ & 8 & 8 & 8 & 8 & abcd \\
\hline 5 & S. $\times$ smithiana 'Semipalatinskiensis ' 89 ' & M & 5.5 & 6 & 12 & 7.83 & abcd \\
\hline 6 & S. $\times$ blanda Andersson ' 247 ' & $\mathrm{F}$ & 3.3 & 8.5 & 11 & 7.6 & abcde \\
\hline 7 & S. viminalis $\times S$. sp. ' 8 ' & M & 2.7 & 7.9 & 11.5 & 7.37 & abcde \\
\hline 8 & S. $\times$ sepulcralis Simonk. '24' & $\mathrm{B}$ & 3 & 3.8 & 13.5 & 6.77 & abcde \\
\hline 9 & S. $\times$ sepulcralis ' 4 ' & $\mathrm{B}$ & 4.2 & 5 & 9.5 & 6.23 & abcde \\
\hline 10 & S. purpurea '70' & $\mathrm{M}$ & 3.5 & 3.2 & 12 & 6.23 & abcde \\
\hline 11 & S. purpurea 'Angustifolia 68' & M & 5 & 7 & 6.5 & 6.17 & abcde \\
\hline 12 & S. purpurea 'Angustifolia 72' & M & 4.5 & 3.5 & 10 & 6 & abcde \\
\hline 13 & S. $\times$ sepulcralis ' 17 ' & M & 2.4 & 4.3 & 10.5 & 5.73 & abcde \\
\hline 14 & S. cinerea L. $\times S$. sp. '205/185' & $\mathrm{F}$ & 4.9 & 3.9 & 8 & 5.6 & abcde \\
\hline 15 & S. eriocephala Michx. '51' & $\mathrm{F}$ & 5.5 & 3.8 & 7.5 & 5.6 & abcde \\
\hline 16 & S. purpurea ' $168 / 155$ ' & $\mathrm{F}$ & 3.5 & 2.1 & 11 & 5.53 & abcde \\
\hline 17 & S. purpurea '7' & $\mathrm{F}$ & 3.5 & 4 & 8.8 & 5.43 & abcde \\
\hline 18 & S. fragilis ' 22 ' & 0 & 4 & 2.9 & 9 & 5.3 & abcde \\
\hline 19 & S. purpurea '87' & $\mathrm{F}$ & 3.8 & 3.2 & 8.5 & 5.17 & abcde \\
\hline 20 & S. purpurea '151/138' & $\mathrm{M}$ & 5 & 3.8 & 6.5 & 5.1 & abcde \\
\hline 21 & S. purpurea ' 126 ' & $\mathrm{F}$ & 2.5 & 4 & 8.5 & 5 & abcde \\
\hline 22 & S. $\times$ pontederana Schleich. ' $196 / 187$ ' & $\mathrm{F}$ & 2.5 & 3.5 & 8.5 & 4.83 & abcde \\
\hline 23 & S. $\times$ rubra Huds. ' 101 ' & $\mathrm{F}$ & 3.4 & 2.5 & 8.5 & 4.8 & abcde \\
\hline 24 & S. triandra ' 122 ' & $\mathrm{F}$ & 3.5 & 7.1 & 3.5 & 4.7 & abcde \\
\hline 25 & S. purpurea '69' & $\mathrm{F}$ & 1.2 & 2.9 & 10 & 4.7 & abcde \\
\hline 26 & S. eriocephala ' 237 ' & $\mathrm{F}$ & 9 & 2.5 & 2.5 & 4.67 & abcde \\
\hline 27 & S. purpurea '74' & M & 4 & 3.2 & 6.8 & 4.67 & abcde \\
\hline 28 & S. purpurea '63' & $\mathrm{F}$ & 1 & 3.1 & 9.5 & 4.53 & bcde \\
\hline 29 & S. purpurea '66' & M & 2.5 & 3.4 & 7.6 & 4.5 & bcde \\
\hline 30 & S. purpurea 'Helix Pyramidalis 160.147 ' & M & 3 & 3.4 & 7 & 4.47 & bcde \\
\hline 31 & S. viminalis ' $65 / 51$ ' & M & 4.2 & 4 & 4.8 & 4.33 & bcde \\
\hline 32 & S. alba L. $\times$ S. triandra '206' & $\mathrm{F}$ & 1.5 & 2.5 & 9 & 4.33 & bcde \\
\hline 33 & S. $\times$ rubra Huds. '49' & $\mathrm{F}$ & 2.2 & 3.2 & 7.5 & 4.3 & bcde \\
\hline 34 & S. purpurea ' 75 ' & $\mathrm{F}$ & 1.7 & 3.2 & 8 & 4.3 & bcde \\
\hline 35 & S. purpurea '79' & $\mathrm{F}$ & 1.5 & 4.5 & 6.4 & 4.13 & bcde \\
\hline 36 & S. fragilis '9' & $\mathrm{F}$ & 2.3 & 2 & 8 & 4.1 & bcde \\
\hline 37 & S. purpurea ' $136 / 123$ ' & M & 2.4 & 3.9 & 5.8 & 4.03 & bcde \\
\hline 38 & S. $\times$ rubra ' 102 ' & $\mathrm{F}$ & 2.2 & 2.2 & 7.4 & 3.93 & bcde \\
\hline 39 & S. triandra $\times$ alba ' 36 ' & $\mathrm{F}$ & 5.5 & 4.8 & 1.5 & 3.93 & bcde \\
\hline 40 & S. $\times$ rubra ' 94 ' & $\mathrm{F}$ & 3.8 & 3 & 5 & 3.93 & bcde \\
\hline 41 & S. purpurea '84' & M & 3.8 & 3.5 & 4.5 & 3.93 & bcde \\
\hline 42 & S. eriocephala ' 253 ' & $\mathrm{F}$ & 3.5 & 3.4 & 4.8 & 3.9 & bcde \\
\hline 43 & S. myrsinifolia Salisb. '52' & $\mathrm{F}$ & 2 & 4.8 & 4.5 & 3.77 & bcde \\
\hline 44 & S. purpurea '67' & M & 3 & 2.2 & 6 & 3.73 & bcde \\
\hline 45 & S. $\times r u b r a$ & $\mathrm{~F}$ & 0.5 & 4.1 & 6.5 & 3.7 & bcde \\
\hline 46 & S. fragilis '95' & M & 6 & 1.5 & 3.5 & 3.67 & bcde \\
\hline 47 & S. triandra ' 33 ' & $\mathrm{F}$ & 5 & 0.9 & 5 & 3.63 & bcde \\
\hline
\end{tabular}


Table 1 (continued)

\begin{tabular}{|c|c|c|c|c|c|c|c|}
\hline \multirow[t]{3}{*}{ No } & \multirow[t]{3}{*}{ Name of taxon } & \multirow[t]{3}{*}{ Sex code } & \multicolumn{3}{|c|}{ Location } & \multirow[t]{3}{*}{ Average } & \multirow[t]{3}{*}{ Tukey's test } \\
\hline & & & S 43 & S 52 & S 85 & & \\
\hline & & & \multicolumn{3}{|c|}{ Mass (kg) } & & \\
\hline 48 & S. $\times$ rubra '26/18' & $\mathrm{F}$ & 2 & 4.4 & 4.5 & 3.63 & bcde \\
\hline 49 & S. purpurea ' 61 ' & $\mathrm{F}$ & 1.6 & 2.9 & 6.4 & 3.63 & bcde \\
\hline 50 & S. purpurea ' 81 ' & $\mathrm{F}$ & 2.8 & 2.4 & 5.7 & 3.63 & bcde \\
\hline 51 & S. cinerea $\times S$. sp. ' 121 ' & 0 & 5.5 & 1.8 & 3.5 & 3.6 & bcde \\
\hline 52 & S. $\times$ rubra ' 28 ' & M & 2 & 2 & 6.8 & 3.6 & bcde \\
\hline 53 & S. purpurea '78' & M & 0.7 & 2.6 & 7.5 & 3.6 & bcde \\
\hline 54 & S. fragilis '214' & $\mathrm{F}$ & 4 & 1 & 5.4 & 3.47 & bcde \\
\hline 55 & S. fragilis '199' & 0 & 3.7 & 1.4 & 5.3 & 3.47 & bcde \\
\hline 56 & S. viminalis '99' & M & 0.9 & 1.5 & 7.8 & 3.4 & bcde \\
\hline 57 & S. $\times$ rubra ' 47 ' & $\mathrm{F}$ & 4.2 & 2.7 & 3.2 & 3.37 & bcde \\
\hline 58 & S. $\times$ sepulcralis ' 11 ' & $\mathrm{B}$ & 0.5 & 4 & 5.5 & 3.33 & bcde \\
\hline 59 & S. $\times$ rubra ' 30 ' & M & 1 & 2.2 & 6.8 & 3.33 & bcde \\
\hline 60 & S. $\times$ rubra ' 64 ' & $\mathrm{F}$ & 1.2 & 1.1 & 7.5 & 3.27 & bcde \\
\hline 61 & S. purpurea ' 82 ' & $\mathrm{F}$ & 3.5 & 1.8 & 4.5 & 3.27 & bcde \\
\hline 62 & S. × smithiana '207/191' & M & 3.4 & 0.8 & 5.3 & 3.17 & bcde \\
\hline 63 & S. triandra ' 205 ' & $\mathrm{F}$ & 1 & 1 & 7.4 & 3.13 & bcde \\
\hline 64 & S. fragilis $\times$ triandra ' 20 ' & M & 1.5 & 2.4 & 5.5 & 3.13 & bcde \\
\hline 65 & S. $\times$ pontederana ' 56 ' & $\mathrm{F}$ & 2.4 & 3.7 & 3.2 & 3.1 & bcde \\
\hline 66 & S. eriocephala '209' & $\mathrm{F}$ & 3.2 & 2.5 & 3.5 & 3.07 & bcde \\
\hline 67 & S. purpurea '149/136' & $\mathrm{F}$ & 2 & 2 & 5 & 3 & bcde \\
\hline 68 & S. eriocephala ' 255 ' & M & 2 & 4 & 3 & 3 & bcde \\
\hline 69 & S. fragilis '239' & M & 3.8 & 2.4 & 2.8 & 3 & bcde \\
\hline 70 & S. purpurea 'Scharfenbergiensis 76' & $\mathrm{F}$ & 1 & 2.7 & 5 & 2.9 & bcde \\
\hline 71 & S. purpurea '57' & $\mathrm{F}$ & 1.5 & 3.5 & 3.7 & 2.9 & bcde \\
\hline 72 & S. purpurea ' $156 / 143$ ' & $\mathrm{F}$ & 1 & 1 & 6.5 & 2.83 & bcde \\
\hline 73 & S. $\times$ smithiana ' 38 ' & M & 1.4 & 2.5 & 4.5 & 2.8 & bcde \\
\hline 74 & S. purpurea '23' & $\mathrm{F}$ & 1.9 & 2 & 4.2 & 2.7 & bcde \\
\hline 75 & S. purpurea '153/140' & $\mathrm{F}$ & 1.5 & 3.2 & 3 & 2.57 & bcde \\
\hline 76 & S. fragilis ' 257 ' & 0 & 2.4 & 1.8 & 3.5 & 2.57 & bcde \\
\hline 77 & S. $\times$ rubra '93' & $\mathrm{F}$ & 0.5 & 0.1 & 7 & 2.53 & bcde \\
\hline 78 & S. $\times$ rubra ' 43 ' & M & 0.5 & 1 & 6 & 2.5 & bcde \\
\hline 79 & S. eriocephala ' 241 ' & $\mathrm{F}$ & 3 & 0.3 & 4 & 2.43 & bcde \\
\hline 80 & S. purpurea '73' & $\mathrm{F}$ & 0.5 & 0.5 & 6 & 2.33 & bcde \\
\hline 81 & S. purpurea ' 125 ' & M & 0.5 & 2 & 3.5 & 2 & cde \\
\hline 82 & S. purpurea '16' & $\mathrm{F}$ & 1 & 1.4 & 3.5 & 1.97 & cde \\
\hline 83 & S. × laurina Sm. '220/205' & 0 & 1 & 2.2 & 2.5 & 1.9 & cde \\
\hline 84 & S. eriocephala '202' & $\mathrm{F}$ & 2 & 0.9 & 2.5 & 1.8 & cde \\
\hline 85 & S. triandra '235' & $\mathrm{F}$ & 1 & 0.3 & 4 & 1.77 & cde \\
\hline 86 & S. purpurea '58' & $\mathrm{F}$ & 1.3 & 2 & 2 & 1.77 & cde \\
\hline 87 & S. myrsinifolia 'Prunifolia 53' & $\mathrm{F}$ & 3 & 1.8 & 0.2 & 1.67 & cde \\
\hline 88 & S. purpurea ' $155 / 142$ ' & 0 & 2 & 0.7 & 2.2 & 1.63 & cde \\
\hline 89 & S. purpurea '39/26' & $\mathrm{F}$ & 0.5 & 2.1 & 2.2 & 1.6 & cde \\
\hline 90 & S. triandra '34' & $\mathrm{F}$ & 1.4 & 1 & 2 & 1.47 & de \\
\hline 91 & S. purpurea ' 77 ' & $\mathrm{F}$ & 0.2 & 2.5 & 1.5 & 1.4 & de \\
\hline 92 & S. eriocephala 'Nicholsoni Purpurescens 204' & $\mathrm{F}$ & 2 & 0.4 & 1.6 & 1.33 & de \\
\hline 93 & S. eriocephala $\times S$. cordata Michx. '210' & $\mathrm{F}$ & 1.2 & 0.2 & 2.5 & 1.3 & de \\
\hline 94 & S. alba 'Chermesina 301/301' & M & 0.5 & 0.9 & 1.5 & 0.97 & $\mathrm{e}$ \\
\hline
\end{tabular}


Table 1 (continued)

\begin{tabular}{|c|c|c|c|c|c|c|c|}
\hline \multirow[t]{3}{*}{ No } & \multirow[t]{3}{*}{ Name of taxon } & \multirow[t]{3}{*}{ Sex code } & \multicolumn{3}{|c|}{ Location } & \multirow[t]{3}{*}{ Average } & \multirow[t]{3}{*}{ Tukey's test } \\
\hline & & & S 43 & S 52 & S 85 & & \\
\hline & & & \multicolumn{3}{|c|}{ Mass (kg) } & & \\
\hline 95 & S. purpurea ' $19 / 15$ ' & M & 0 & 2.5 & 13 & 5.17 & - \\
\hline 96 & S. $\times$ smithiana '44' & M & 0 & 7.2 & 8 & 5.07 & - \\
\hline 97 & S. $\times$ sepulcralis ' $162 / 143$ ' & $\mathrm{B}$ & 6.5 & 6.8 & 0 & 4.43 & - \\
\hline 98 & S. purpurea ' 71 ' & $\mathrm{F}$ & 0 & 3.9 & 9 & 4.3 & - \\
\hline 99 & S. fragilis ' 25 ' & 0 & 0 & 3 & 8 & 3.67 & - \\
\hline 100 & S. purpurea '26' & M & 1 & 0 & 9 & 3.33 & - \\
\hline 101 & S. ×rubra '66/52' & $\mathrm{F}$ & 2.8 & 0 & 6.5 & 3.1 & - \\
\hline 102 & S. purpurea 'Angustifolia 159/146' & M & 4.5 & 0 & 3 & 2.5 & - \\
\hline 103 & S. $\times$ sepulcralis ' 40 ' & $\mathrm{B}$ & 7 & 0 & 0 & 2.33 & - \\
\hline 104 & S. purpurea ' 65 ' & $\mathrm{F}$ & 0 & 1.5 & 5.5 & 2.33 & - \\
\hline 105 & S. $\times$ rubra ' 223 ' & $\mathrm{F}$ & 0 & 0 & 6.8 & 2.27 & - \\
\hline 106 & S. $\times$ smithiana '221/206' & M & 6 & 0 & 0.2 & 2.07 & - \\
\hline 107 & S. $\times$ laurina '216' & $\mathrm{F}$ & 2.5 & 3.5 & 0 & 2 & - \\
\hline 108 & S. purpurea ' $158 / 145$ ' & $\mathrm{F}$ & 0.5 & 0 & 5.5 & 2 & - \\
\hline 109 & S. purpurea '167/154' & $\mathrm{F}$ & 0 & 1.2 & 4.5 & 1.9 & - \\
\hline 110 & S. fragilis ' 45 ' & $\mathrm{B}$ & 0 & 1.8 & 3.7 & 1.83 & - \\
\hline 111 & S. purpurea ' 21 ' & $\mathrm{F}$ & 0.8 & 0 & 4.5 & 1.77 & - \\
\hline 112 & S. $\times$ rubra '96' & $\mathrm{F}$ & 0 & 2.1 & 3 & 1.7 & - \\
\hline 113 & S. purpurea '83' & $\mathrm{B}$ & 2.2 & 2.9 & 0 & 1.7 & - \\
\hline 114 & S. cinerea $\times$ S. triandra ' $186 / 171$ ' & $\mathrm{F}$ & 5 & 0 & 0 & 1.67 & - \\
\hline 115 & S. fragilis ' $197 / 182$ ' & 0 & 1.2 & 0 & 3.8 & 1.67 & - \\
\hline 116 & S. purpurea ' 86 ' & M & 0 & 0 & 5 & 1.67 & - \\
\hline 117 & S. alba ' 225 ' & 0 & 0 & 0 & 4.8 & 1.6 & - \\
\hline 118 & S. fragilis 'Monspeliensis ' $46 / 32$ ' & 0 & 3 & 1.2 & 0 & 1.4 & - \\
\hline 119 & S. $\times$ rubra '29' & M & 0 & 0.9 & 2.8 & 1.23 & - \\
\hline 120 & S. eriocephala 'Nicholsoni Purpurescens 150/137' & $\mathrm{F}$ & 2.5 & 1.2 & 0 & 1.23 & - \\
\hline 121 & S. reichardtii Kern. '50' & $\mathrm{F}$ & 1 & 2.1 & 0 & 1.03 & - \\
\hline 122 & S. fragilis ' 249 ' & 0 & 1 & 2 & 0 & 1 & - \\
\hline 123 & S. acutifolia Willd. '124' & $\mathrm{F}$ & 0 & 1.9 & 1 & 0.97 & - \\
\hline 124 & S. alba $\times$ triandra ' 234 ' & 0 & 2 & 0 & 0 & 0.67 & - \\
\hline 125 & S. purpurea '60' & $\mathrm{F}$ & 2 & 0 & 0 & 0.67 & - \\
\hline 126 & S. fragilis ' 231 ' & 0 & 0.8 & 0 & 0 & 0.27 & - \\
\hline 127 & S. $\times$ rubens Schrank. '178/164' & $\mathrm{F}$ & 0.6 & 0 & 0 & 0.2 & - \\
\hline
\end{tabular}

A value of " 0 " in the "Mass" columns means that the plant did not survive after 3 years of cultivation. In the "Sex code" column, 0 denotes genotypes for which the sex was not determined, $\mathrm{F}$ indicates female, $\mathrm{M}$ indicates male, and B indicates bisexual; the values in columns are the averages for replications from each location

hybrids and cultivars differentiated by sex and varieties. The list of genotypes is shown in Table 1 . In accordance with the design (Fig. 1) the research areas described in this paper included a total of 18 plots (4, 6 and 8 , respectively) in which 8100 plants were planted ( 3 cuttings of each genotype $\times 150$ genotypes $\times 18$ plots). All cuttings were of a similar length $(29-30 \mathrm{~cm})$ and thickness $(0.7-10 \mathrm{~mm})$. Before planting the soil was ploughed and harrowed. Next, soaked cuttings were planted at a depth of about $25 \mathrm{~cm}(5 \mathrm{~cm}$ being left above the ground). The planting was carried out by hand.
All plants growing on the indicated plots (Fig. 1a-c-black rectangles) were cut in January 2014 and further analyzed.

\section{Sex determination}

Sex was determined in the third vegetation season (the year 2013) directly at experimental plots. Willows are generally dioecious, but among the tested genotypes there were willows with male and female catkins on the same shrub or willows with male and female features in one catkin (mainly 
Salix $\times$ sepulcralis and single genotypes of $S$. fragilis and $S$. purpurea). There were also some plants without any catkins (mainly S. fragilis), and in such cases it was impossible to determine the sex. Therefore, all genotypes were divided into four categories: 0 - with indeterminate sex, 1 -females, 2-males, and 3-willows with separate male and female catkins on the same shrub or willows with male and female features in one catkin.

\section{Biomass measurements}

The measurements of biomass were performed in January 2014 after three full vegetation seasons (years: 2011, 2012, 2013), after growth cessation and leaf fall, when the shoots and root age was 3 years. All living shoots of each plant were cut at $5 \mathrm{~cm}$ above the shoot base, and the plant fresh weight was determined by weighing all shoots of each taxon in the field using a field hook balance with an accuracy of $10 \mathrm{~g}$. Fresh weight instead of dry weight was measured as the cut shoots were to be used for the next experiment and had to be live.

\section{Leaf feature measurements}

Leaf features were measured with the digiShape computer program. For each taxon in July 2013, 100 leaves were picked from the outer part of the crown, at half the height of the shrub, 25 from the N, S, W and $\mathrm{E}$ directions. The leaves were then scanned and prepared for measurement. 50 leaves from each taxon were scanned from the upper side of the leaf blade and 50 from the lower side (Figs. 2, 3). Thus, length, width, elongation, area of leaf blade and length of petiole were measured.

\section{Statistical analysis}

The following correlations were evaluated: habitat and shoot mass; sex and shoot mass; leaf traits and sex. To perform the statistical calculations, genotypes were divided-in accordance with their relationships-into 24 main groups numbered from 1 to 24 (Table 2), representing basic species and hybrids between species. The basic groups were divided into subdivisions according to differences in sex or other features and sequentially numbered as N.1, N.2, etc. The
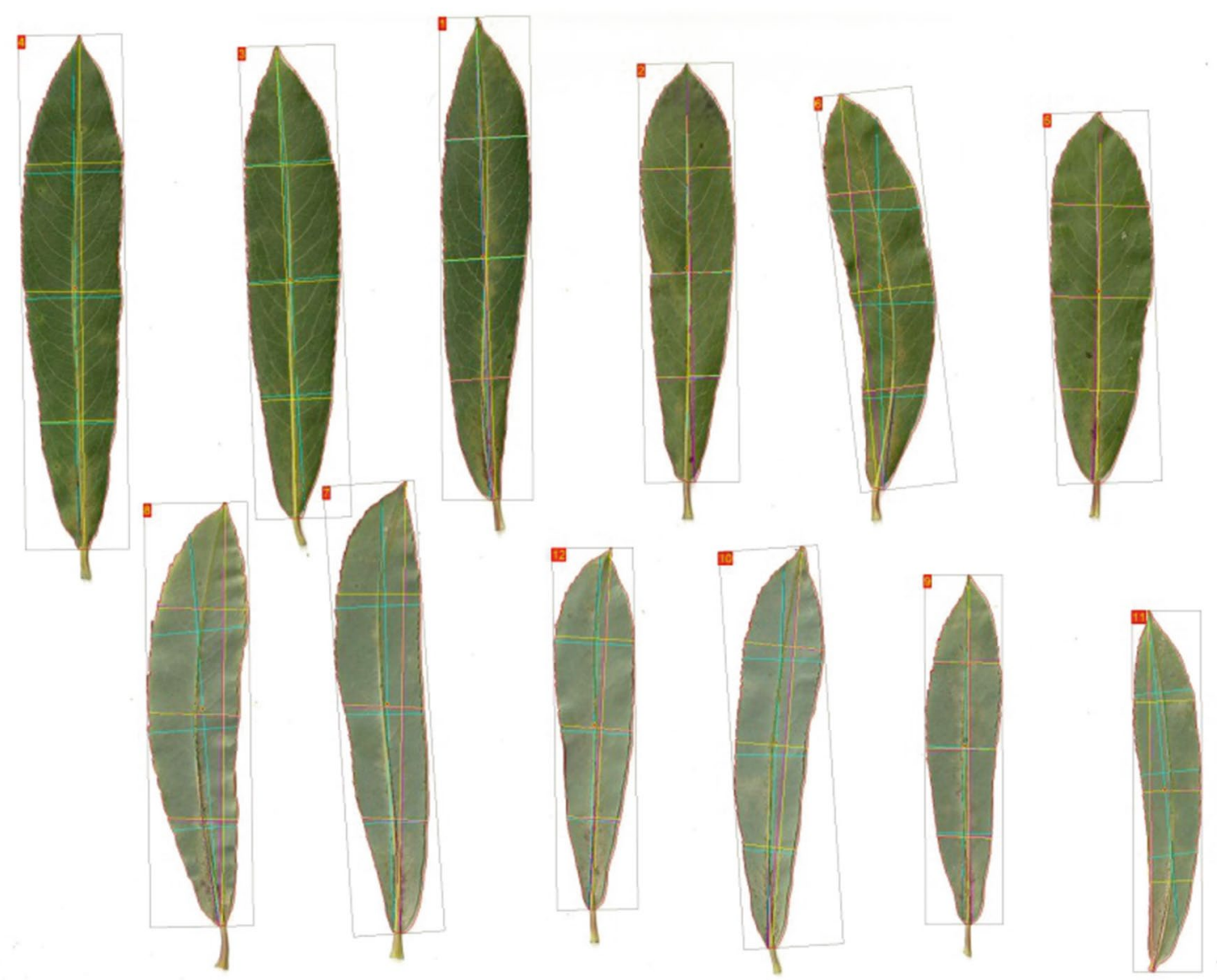

Fig. 2 Scanned and measured leaves of Salix purpurea ' 65 ', $q$ 


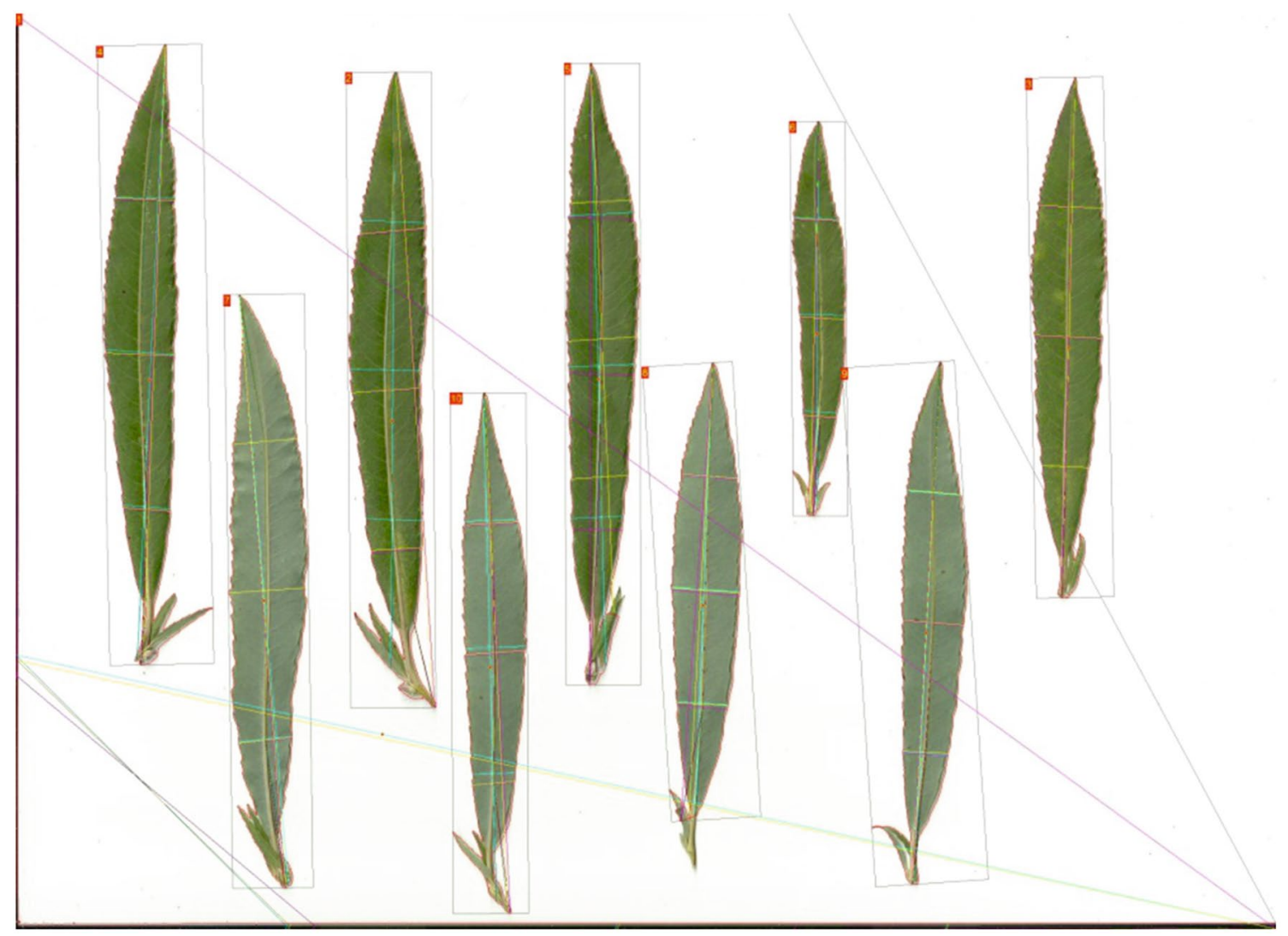

Fig. 3 Scanned and measured leaves of Salix purpurea $\times$ triandra $\times$ viminalis ' 15 ',

greatest number of units (46) was distinguished in $S$. purpurea (17.11-17.56). Groups 1, 4, 8, 11, 13, 20 and 22-24 were represented by a single taxon only.

Shoot mass analysis of variance was used according to the model

$y_{i j k l}=\mu+\alpha_{i}+\beta_{j}+\gamma_{k}+\left(\alpha_{i} \beta_{j}\right)+e_{i j k l}$,

where, $\mu$ is the overall average, $\alpha_{i}$ is the the effect of sex, $i=1,2, \ldots, 4, \beta_{j}$ is the the effect of location, $j=1,2,3, \gamma_{k}$ is the the effect of taxon, $k=1,2, \ldots, 91, \alpha_{i} \beta_{j}$ is the the effect of the interaction between $i$-sex and $j$-location, $e_{i j k l}$ is the random error.

For comparisons of the average shoot mass, multiple comparisons on the basis of Tukey's method according to Ott (1984) were performed.

\section{Results}

\section{Mortality}

150 genotypes of willows were planted on each plot; however, after 3 years of cultivation a total of 94 genotypes survived in all tested plots (Fig. 1a-c black rectangles). Some of the willow genotypes died at one or two of the three given plots: S-43-13 genotypes, S-52-16 and S-85-13 genotypes (Fig. 4) and 23 genotypes did not survive in any of the studied areas.

From the data presented in Fig. 4, it appears that the female genotypes showed the highest mortality, although it should be noted that among all tested willows female genotypes (category F) were definitely dominant $(56.7 \%$ of all genotypes). The other sex categories showed the following shares: genotypes without flowers for which sex was not determined (category 0)—10.2\%, males (category M) $-27.6 \%$ and bisexual (category B)-5.5\%. Therefore, the variation in the willows of the different sex categories in terms of the percent mortality, as shown in Fig. 5, differs from that shown by the willows when considering survival according to number.

Figure 5 also shows that bisexual specimens (generally hybrids) and specimens of unspecified sex had the highest mortality, which in turn may be a sign of their generally worse condition in comparison to that shown by the other sex categories, and this is emphasized by the lack of flowering. Additional conclusions can also be drawn from Fig. 5 . It can be seen that for male specimens the $\mathrm{S}-85$ area proved 
Table 2 List of Salix genotypes and the average mass of shoots (kg); abbreviations: 0indeterminate sex, $\mathrm{F}$-female, $\mathrm{M}$-male, B-bisexual, Ttotal

\begin{tabular}{|c|c|c|c|c|c|c|c|c|c|c|c|}
\hline \multirow[t]{2}{*}{ No } & \multirow[t]{2}{*}{ Name of taxon } & \multicolumn{5}{|c|}{ Number of tested genotypes } & \multicolumn{5}{|c|}{$\begin{array}{l}\text { Average mass }(\mathrm{kg}) \text { of single } \\
\text { shrub of tested genotypes }\end{array}$} \\
\hline & & 0 & $\mathrm{~F}$ & $\mathrm{M}$ & $\mathrm{B}$ & $\mathrm{T}$ & 0 & $\mathrm{~F}$ & $\mathrm{M}$ & $\mathrm{B}$ & $\mathrm{T}$ \\
\hline 1 & Salix $\times$ blanda & & 1 & & & 1 & & 7.6 & & & 7.6 \\
\hline 2 & S. $\times$ laurina & 1 & 1 & & & 2 & 1.9 & 2.0 & & & 2.0 \\
\hline 3 & S. $\times$ pontederana & & 2 & & & 2 & & 4.0 & & & 4.0 \\
\hline 4 & S. $\times$ rubens & & 1 & & & 1 & & 0.2 & & & 0.2 \\
\hline 5 & S. $\times r u b r a$ & & 12 & 4 & & 16 & & 3.4 & 2.7 & & 3.2 \\
\hline 6 & S. $\times$ sepulcralis & & & 1 & 5 & 6 & & & 5.7 & 4.6 & 4.8 \\
\hline 7 & S. $\times$ smithiana & & 1 & 6 & & 7 & & 8.0 & 4.9 & & 5.3 \\
\hline 8 & S. acutifolia & & 1 & & & 1 & & 1.0 & & & 1.0 \\
\hline 9 & S. alba & 1 & & 1 & & 2 & 1.6 & & 1.0 & & 1.3 \\
\hline 10 & S. alba $\times$ S. triandra & 1 & 1 & & & 2 & 0.7 & 4.3 & & & 2.5 \\
\hline 11 & S. cinerea $\times$ S. triandra & & 1 & & & 1 & & 1.7 & & & 1.7 \\
\hline 12 & S. cinerea $\times S$. sp. & 1 & 1 & & & 2 & 3.6 & 5.6 & & & 4.6 \\
\hline 13 & S. eriocephala $\times S$. cordata & & 1 & & & 1 & & 1.3 & & & 1.3 \\
\hline 14 & S. eriocephala & & 8 & 1 & & 9 & & 3.0 & 3.0 & & 3.0 \\
\hline 15 & S. fragilis & 8 & 2 & 2 & 1 & 13 & 2.4 & 3.8 & 3.4 & 1.8 & 2.7 \\
\hline 16 & S. myrsinifolia & & 2 & & & 2 & & 2.8 & & & 2.8 \\
\hline 17 & S. purpurea & 1 & 28 & 16 & 1 & 46 & 1.6 & 3.2 & 4.2 & 1.7 & 3.4 \\
\hline 18 & S. purpurea $\times$ triandra $\times$ viminalis & & 2 & & & 2 & & 10.3 & & & 10.3 \\
\hline 19 & S. triandra & & 5 & & & 5 & & 2.9 & & & 2.9 \\
\hline 20 & S. triandra $\times$ alba & & 1 & & & 1 & & 3.9 & & & 3.9 \\
\hline 21 & S. viminalis & & & 2 & & 2 & & & 3.9 & & 3.9 \\
\hline 22 & S. viminalis $\times S$. sp. & & & 1 & & 1 & & & 7.4 & & 7.4 \\
\hline 23 & S. fragilis $\times$ triandra & & & 1 & & 1 & & & 3.1 & & 3.1 \\
\hline 24 & S. reichardtii & & 1 & & & 1 & & 1.0 & & & 1.0 \\
\hline Total & & 13 & 72 & 35 & 7 & 127 & 2.2 & 3.4 & 4.0 & 3.8 & 3.5 \\
\hline
\end{tabular}

Fig. 4 Total number of genotypes that did not survive the 3 years of cultivation at locations S-43, S-52 and S-85 according to sex category. Legend: 0 genotypes without flowers for which sex was not determined, $\mathrm{F}$-female, $\mathrm{M}$-male, $\mathrm{B}$ bisexual

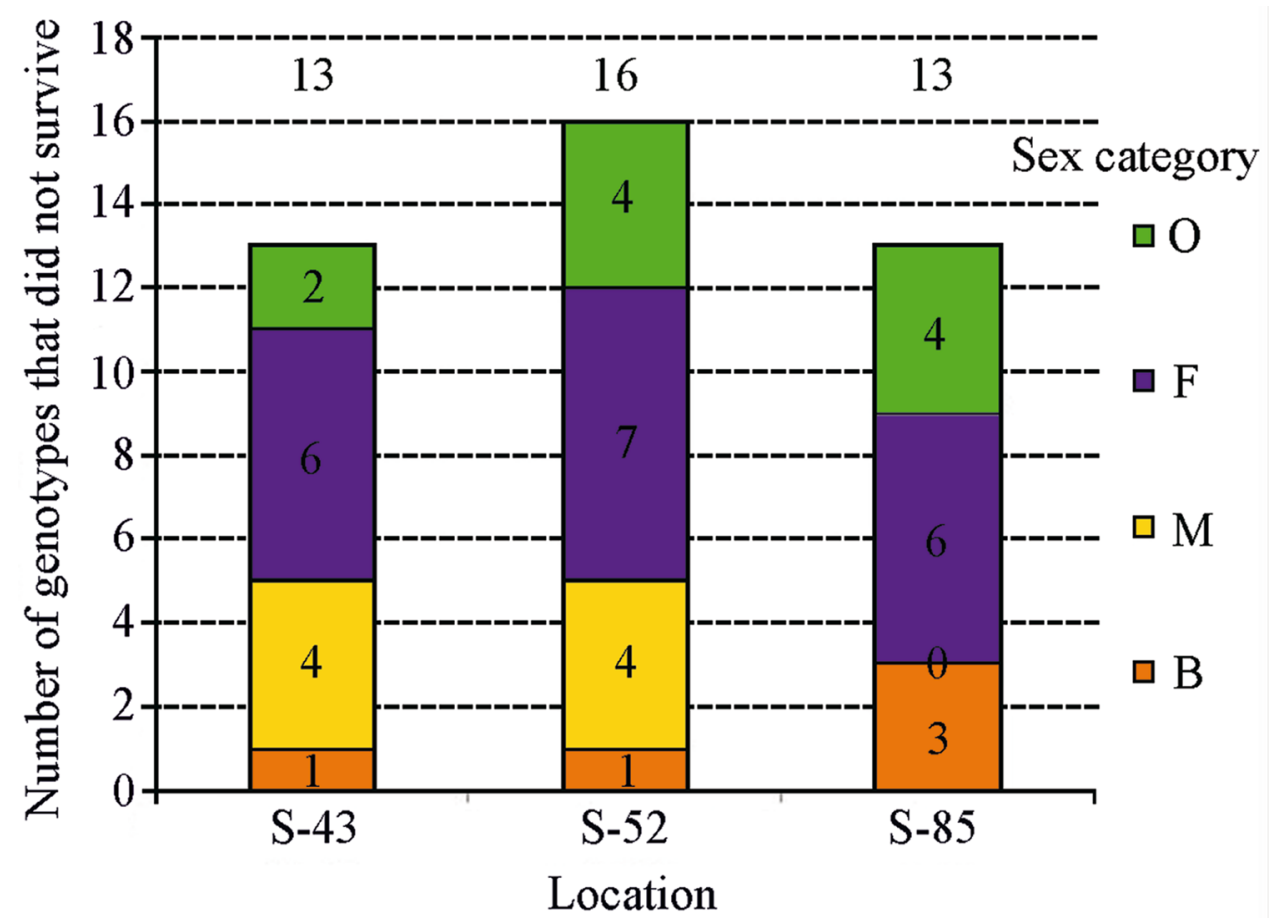


Fig. 5 Mortality (in \%) of different genotypes following 3 years of cultivation according to sex category. Legend: 0 genotypes for which sex was not determined, $\mathrm{F}$-female, $\mathrm{M}$ male, B-bisexual

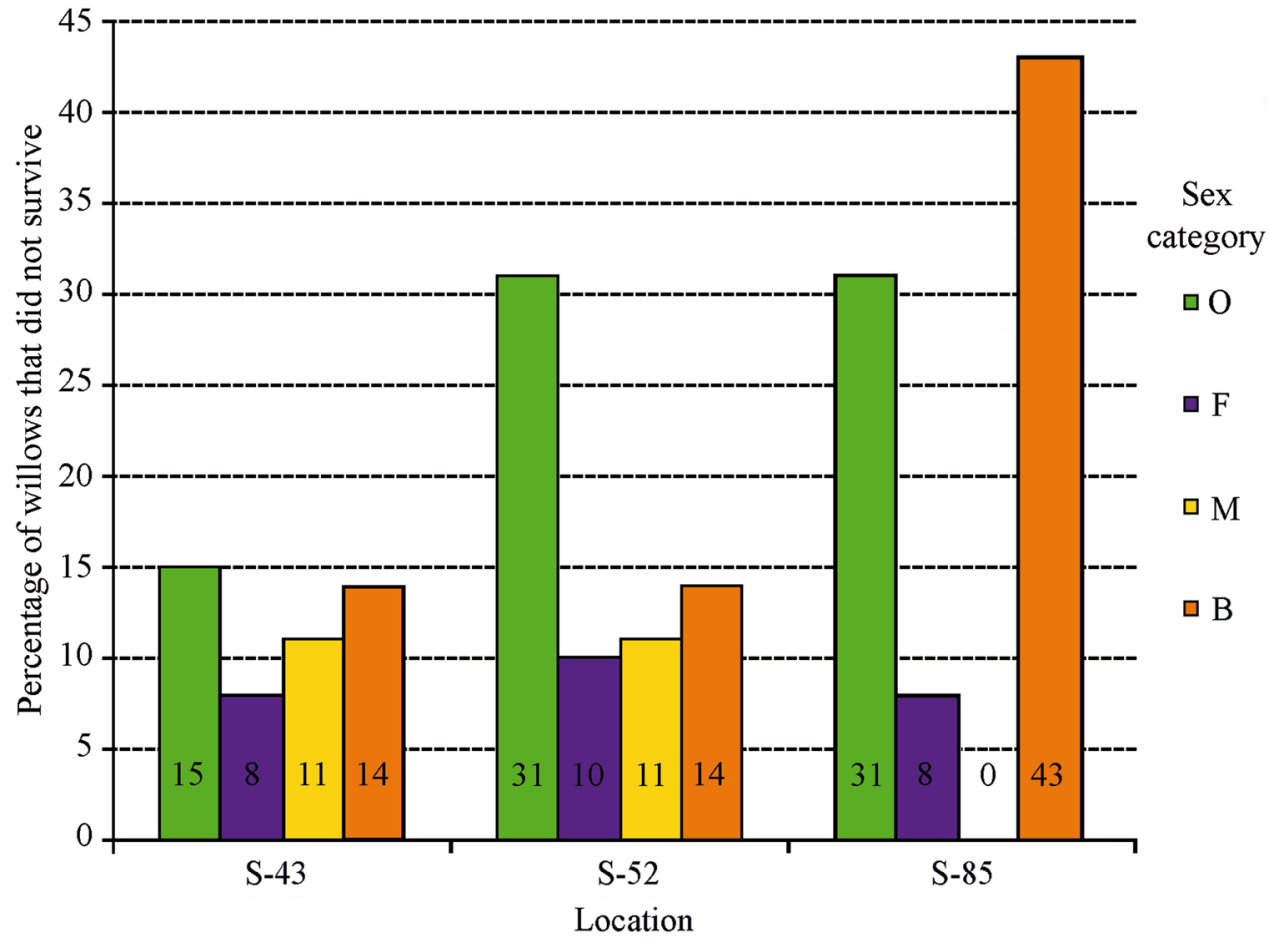

to be the most beneficial, as all male genotypes survived the 3 years of cultivation (mortality $=0$ ), while female specimens showed similar mortality across all three locations. It is worth noting, however, that the survival of female specimens was higher at the S-43 and S-52 locations than that of male specimens. Considering the soil conditions prevailing across all three research areas, among which the most favorable prevailed at the S-85 location, it can be argued that in better habitat conditions, male specimens have lower mortality, but when the conditions worsen, females survive better.

Finally, considering the mortality across all 150 genotypes, 127 were further examined, including 13 genotypes with indeterminate sex, 72 females, 35 males and 7 genotypes with male and female catkins on the same shrub (Tables 1 and 2) that survived in at least one of the three study areas (S-43, S-52, S-85).

\section{Biomass: site interactions}

The biomass - site interaction data are given in Fig. 6.

The weight of the shoots of willows growing at the S-85 location was twice as high as that at the other locations (S-43 and S-52). Due to the close proximity of the research areas, it could be assumed that of the three factors included in the term "habitat" (climate, soil and location), the key role in the differentiation of the tested plants was played by soil, especially the water regime and water balance. At location $\mathrm{S}-52$, the soil is composed of clay. It is fertile ground but the supply of water depends on rain and snowfall, which are variable across years in Poland, e.g., from $311.6 \mathrm{~mm}$ in 1989 to $723.6 \mathrm{~mm}$ per year in 1993 (Rutkowski et al. 2007). Old shrubs, which have deep root systems, can survive unfavorable years but for young plants, such conditions may have critical effects.

At site S-43 the soil is sandy, with the groundwater level at a depth of $1.50 \mathrm{~m}$. For older shrubs such a situation is favorable but for young plants the first years of cultivation are vital because their root systems must be sufficiently long to reach the water. Optimal site conditions were noted at location S-85, where the soil is composed of silt and the groundwater level is at a depth of $0.95 \mathrm{~m}$. These conditions were reflected in the high yield from this site. The biomass values given in Fig. 5 refer to the total mass of shoots of all 127 genotypes tested separately at each plot. At a spacing of $0.5 \times 1.5 \mathrm{~m}$, each plant occupied $0.75 \mathrm{~m}^{2}$, while all plants occupied a total area of $285.75 \mathrm{~m}^{2}$ per plot. Thus, in the particular plots, all the evaluated willows had a fresh shoot mass of $1.14 \mathrm{~kg} / \mathrm{m}^{2}(\mathrm{~S}-43), 1.15 \mathrm{~kg} / \mathrm{m}^{2}(\mathrm{~S}-52)$, and $2.36 \mathrm{~kg} /$ $\mathrm{m}^{2}(\mathrm{~S}-85)$.

\section{Biomass: taxon interactions}

The most important factor affecting the tested plants was taxonomic identity. Among the 127 tested genotypes the largest shoot mass occurred in 2 genotypes of $S$. purpurea $\times$ triandra $\times$ viminalis (Table 1 ). After 3 years of cultivation hybrid S. purpurea $\times$ triandra $\times$ viminalis ' 15 ' produced an average, calculated from all three localities together, of $11.5 \mathrm{~kg}$ per shrub of fresh shoot mass, (S-43-14.5 kg, S-53-12.0 kg, 
Fig. 6 Comparison of the total biomass at each studied plot [S-43 (Fig. 1a); S-52 (Fig. 1b) and S-85 (Fig. 1c)] and the soil characteristics of each area

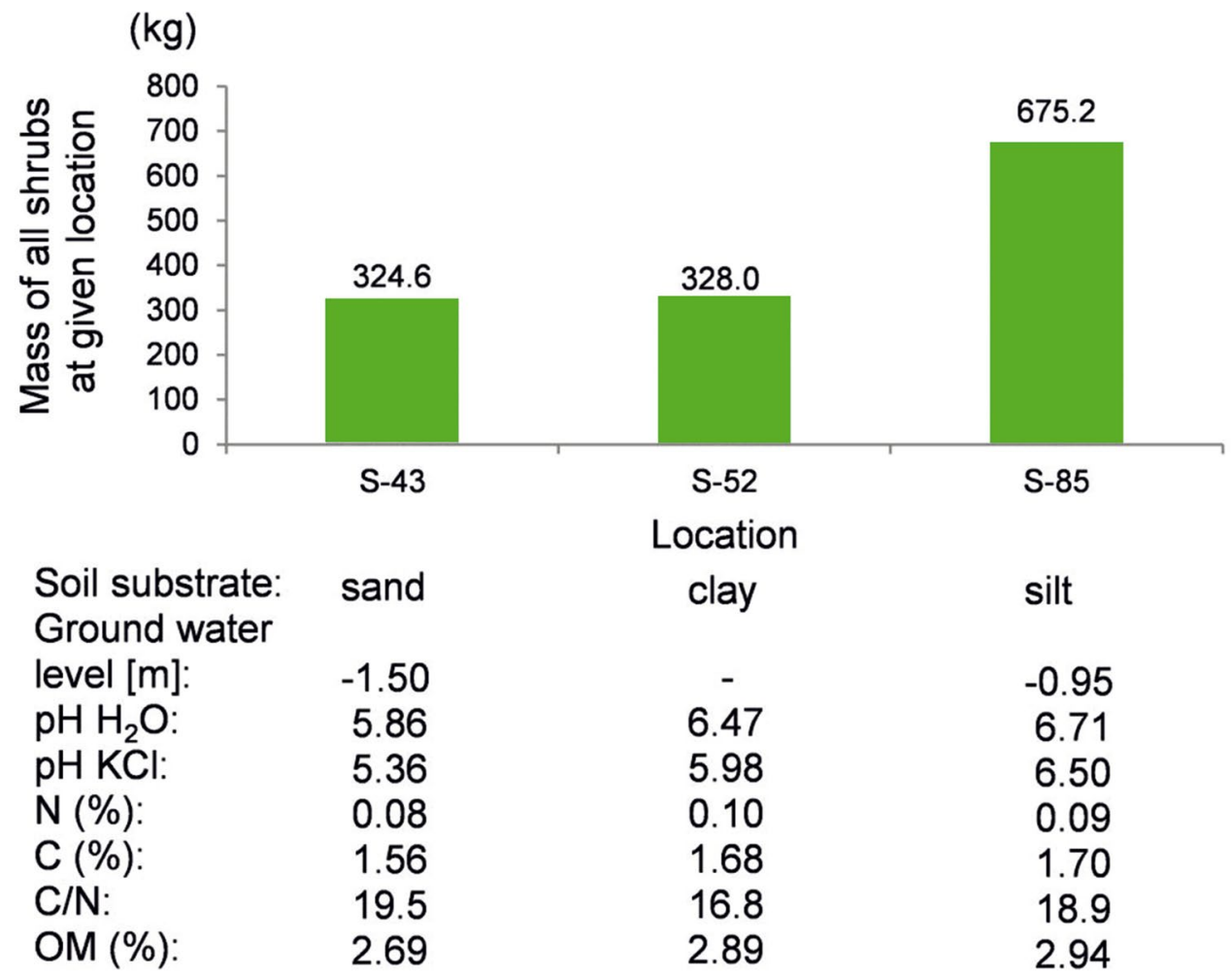

S-85-8.0 kg), while $S$. purpurea $\times$ triandra $\times$ viminalis ' 46 ' produced $9.0 \mathrm{~kg}(5.0,9.5$, and $12.5 \mathrm{~kg}$, respectively). A summary of the biomass production of the tested genotypes is shown in Fig. 7.
For the willows that survived the 3-year study period at each of the three locations described above (94 of 127 genotypes), an analysis of variance was performed. The results of the analysis showed significant correlations between the

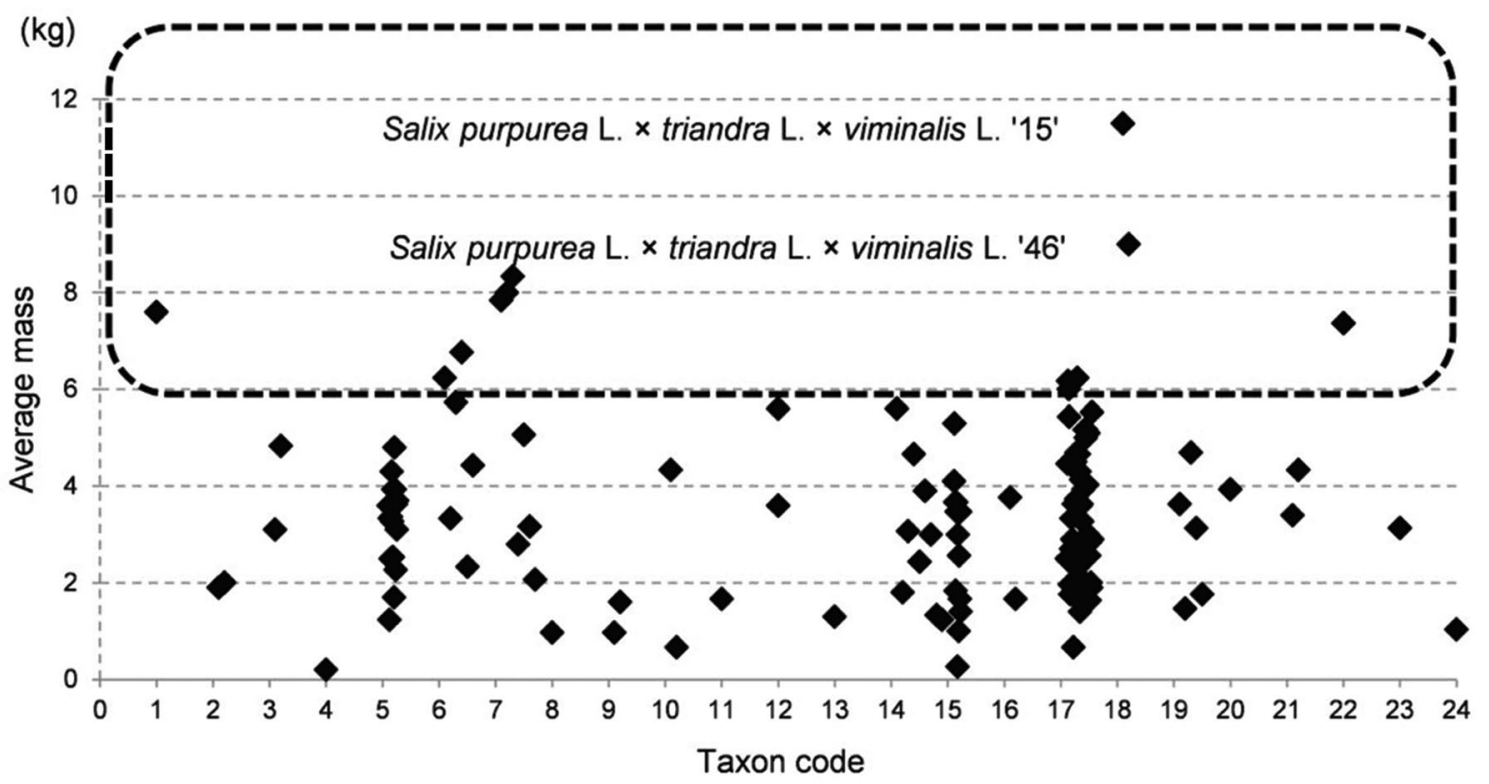

Fig. 7 Differentiation of the average fresh biomass of shoots of 3 -year-old shrubs among all (127) tested genotypes. Species and hybrids were coded according to natural numbers from 1 to 24
(Table 1). The codes of all genotypes are given in Table 4. Each black point denotes one genotype. The dashed line indicates the best-growing willow genotypes (all top genotypes are hybrids) 
mass of shoots and location, the mass of shoots and taxon, and the mass of shoots and sex (Table 4).

For the genotypes that survived at all three locations (Table 1, positions 1-94), Tukey's test was also performed. Table 1 also includes genotypes for which Tukey's test, due to an insufficient number of replicates (absence of the taxon at one or two of the three locations), was not carried out. These genotypes were, however, included in Table 1 (positions 95-127) to show that under suitable site conditions, the biomass of shrubs could be relatively high even if the survivability of a given taxon is generally low.

The results of Tukey's test, presented in a Venn diagram (Fig. 8), clearly confirm the separation of the genotypes with the highest $(S$. purpurea $\times$ triandra $\times$ viminalis—letter "a") and lowest (S. alba 'Chermesina'-letter "e") biomass.

\section{Biomass: sex interactions}

Tukey's test performed for 94 genotypes revealed 3 different groups of willows:

group "a"-bisexual specimens (Table 3: C3),

group "ab"-male (Table 3: C2) and female (Table 3: C1) specimens,

group "b"-specimens of indeterminate sex (Table 3: $\mathrm{C} 0$ ).

The results are also shown in Fig. 9 and Table 1.

The results of the 3 -factor analysis of variance for the 94 genotypes of willows in regard to the interactions of sexbiomass, location-biomass, taxon-biomass and sexlocation are shown in Table 4. Of course, the evaluation of the sex-location interaction does not make sense, but the "interaction insignificant" result was kept in Table 4 because it shows the correctness of the test and strengthens the significance of the other demonstrated interactions.

\section{Biomass: leaf feature and sex-leaf feature interactions}

For S. purpurea, which represents the largest number of genotypes among all the tested genotypes (46 of a total of 127), an analysis of the relationships between location, biomass and leaf traits was also performed to evaluate:

1. the influence of leaf characteristics on biomass,

2. the relationships between leaf traits and sex.

For this purpose, 35 genotypes of $S$. purpurea that survived at all 3 locations (S-43, S-52 and S-85) were analyzed. Among these 35 genotypes, 3 sex categories were distinguished: indeterminate sex ( 1 genotype), female (23 genotypes) and male (11 genotypes) (Table 5$)$. Their masses are illustrated by a heat map in which two-dimensional variables are represented by different colors (Fig. 10). Cluster

Table 3 The results of Tukey's test performed for 94 genotypes divided into 4 sex groups $(\mathrm{C} 0$ - indeterminate sex, $\mathrm{C} 1$ - female, $\mathrm{C} 2$ male, C3-bisexual) tested in 3 locations; $R$ number of genotypes in given sex category $\times 3$ plots

\begin{tabular}{llllrl}
\hline Group & Average $( \pm \mathrm{SD})$ & $R$ & Min & Max & Tukey's test \\
\hline C3 & $5.44(3.85)$ & 9 & 0.5 & 13.5 & $\mathrm{a}$ \\
$\mathrm{C} 2$ & $4.31(2.84)$ & 84 & 0.5 & 12.0 & $\mathrm{ab}$ \\
$\mathrm{C} 1$ & $3.83(2.82)$ & 171 & 0.1 & 14.5 & $\mathrm{ab}$ \\
$\mathrm{C} 0$ & $3.08(1.99)$ & 18 & 0.7 & 9.0 & $\mathrm{~b}$ \\
\hline
\end{tabular}

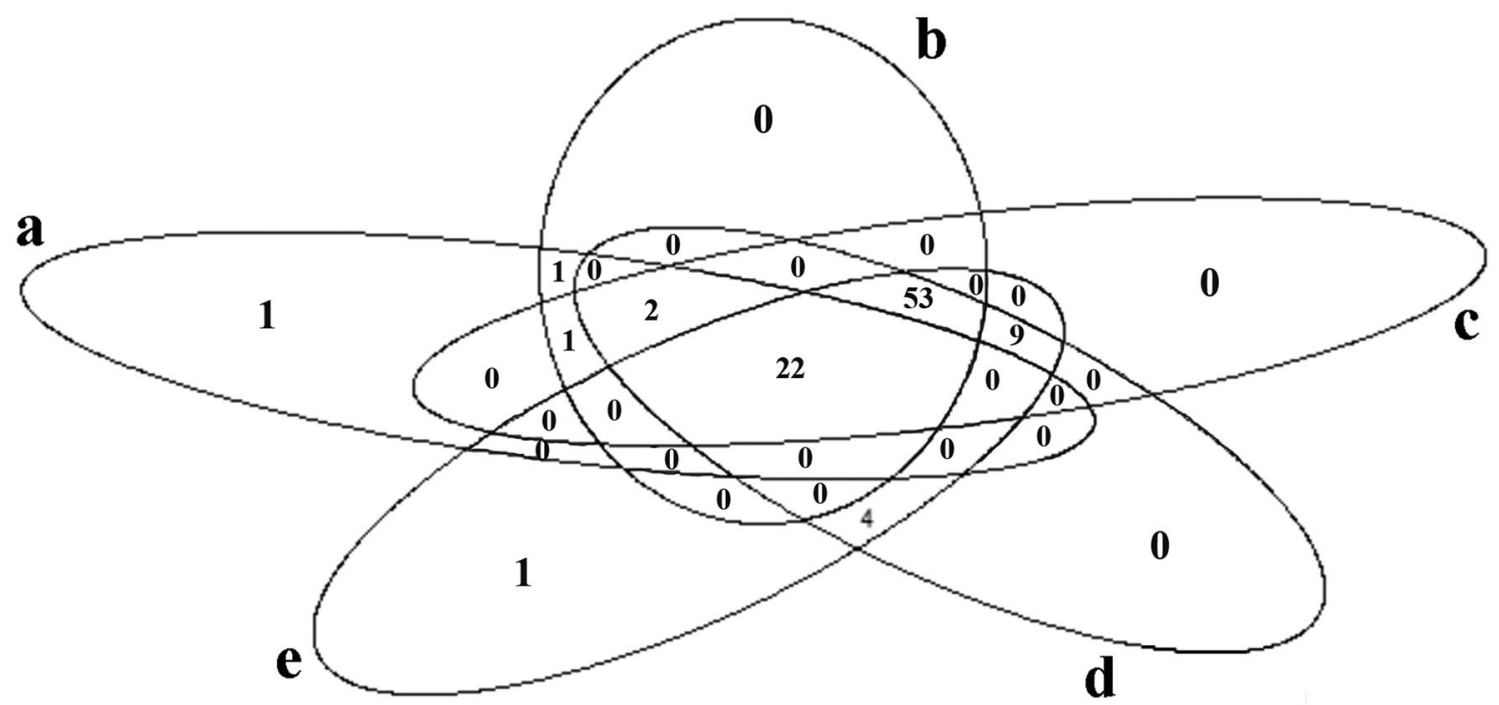

Fig. 8 Venn diagram for 94 genotypes evaluated with Tukey's test. Letters "a" to "e" denote relations between the genotypes of willows with the highest (a) to lowest biomass (e) 


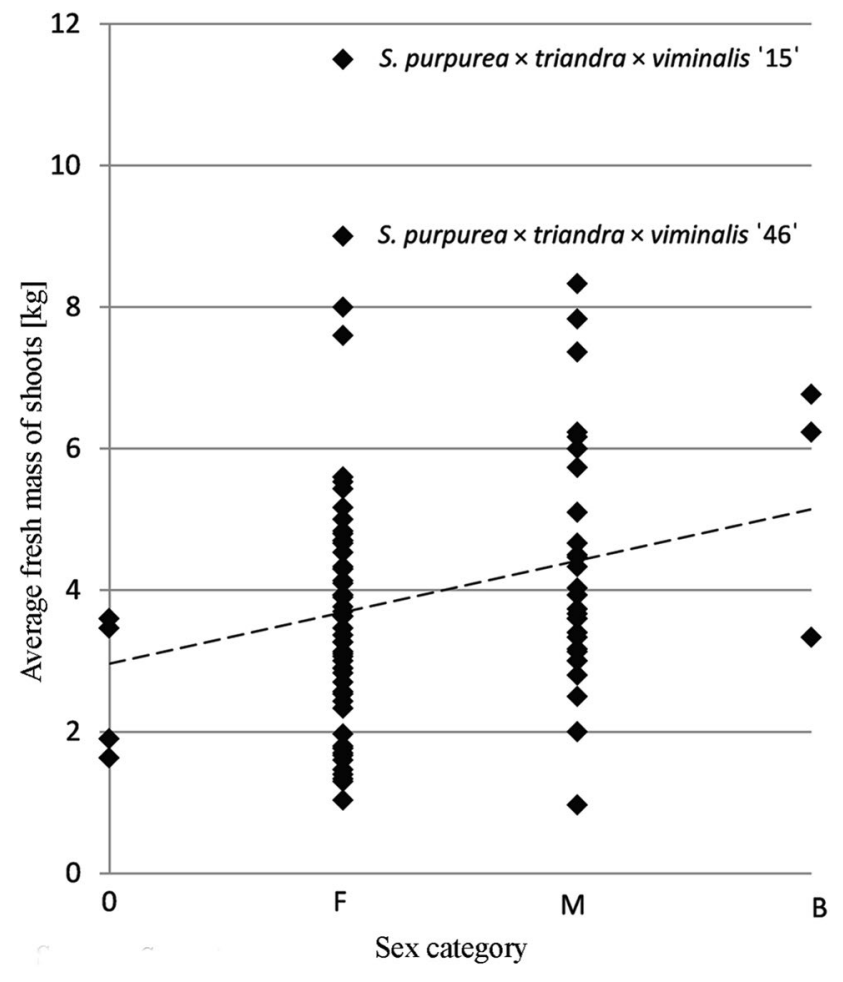

Fig. 9 Average fresh mass of shoots (in $\mathrm{kg}$ ) for 94 genotypes grouped into 4 sex categories. Sex category 0 - genotypes for which sex was not determined, $\mathrm{F}-$ female, $\mathrm{M}-$ male, $\mathrm{B}$-bisexual

analysis enabled the grouping of the analyzed genotypes by location in such a way that the degree of combinations within one group was the largest, while that between groups was the smallest. Using Ward's hierarchical clustering and the measure of Euclidean distance a tree diagram with three clusters (Fig. 10) was obtained.

In the heat map shown in Fig. 10, the differences between location S-85 and the others are clearly visible. Sex differences are less prominent, although the analysis of genotypes belonging to particular groups clearly shows these differences. Female specimens dominate in group 1, which accounts for $39 \%$ of all plants in this sex category (26\% in group 2, 35\% in group 3). Male specimens were strongly concentrated in group 3 (73\%). Specimens for which sex was not determined occurred only in group 1.
In an attempt to identify common features of the genotypes in individual clusters, an analysis of leaf traits of $S$. purpurea, comprising the leaf area, leaf blade length and width, leaf slenderness (length-width ratio), and petiole length, was conducted. All data were given in the Catalogue of Willows published by Rutkowski et al. (2013). The genotypes grouped into cluster 1 had, on average, the shortest petioles $(4.8 \mathrm{~mm})$, the shortest length of the leaf blade $(70.5 \mathrm{~mm})$ and the smallest leaf width (14.6). The petioles of the genotypes grouped into cluster 2 were the longest (average $6.5 \mathrm{~mm}$ ). The genotypes grouped into cluster 2 also had the longest $(75.6 \mathrm{~mm})$ and the widest $(16.8 \mathrm{~mm})$ leaf blades on average.

Statistical analysis of the leaf traits showed their relationship to sex (Table 6). On average, male specimens have longer and wider leaves and thus a larger leaf area than specimens in the other two sex categories. They also have the longest petioles by far. The smallest leaves and the shortest petioles were found in willows of indeterminate sex (one genotype). Longer petioles may help the leaves move more efficiently towards the sun. In addition to a longer and wider leaf blade, this trait may affect biomass production through the better use of solar energy in photosynthesis.

\section{Discussion}

Approximately 18 willow species show exceptions from dioecy. Thirteen of them occur naturally, three arose in experiments and two are found under both natural and experimental conditions (Mirski 2014). The main objective of this study was to test whether the sex of different willow species affects their biomass and mortality, but the results show that we can add 2 more to the list of 18 species mentioned by Mirski: S. fragilis and S. purpurea. The conducted studies also included bisexual $S . \times$ sepulcralis, which is a hybrid of S. babylonica L. $\times$ S. alba L., but bisexual catkins are not rare in hybrids (Stace 1999).

Yang et al. (2020) have shown that the mortality of male individuals of $S$. suchowensis is higher than females. Our results confirmed the impact of site conditions on the mortality of males and females but indicated that male specimens show higher survival when they grow under better
Table 4 The results of the three-factor analysis of variance for 94 genotypes of willows

\begin{tabular}{llccrll}
\hline Interactions & $d f$ & Sum of squares & Mean square & \multicolumn{1}{l}{$l$} & $p$ & Level of significance \\
\hline Sex-biomass & 3 & 46.6 & 15.55 & 4.219 & 0.00653 & $* *$ \\
Location-biomass & 2 & 599.5 & 299.76 & 81.332 & $<2 \mathrm{e}-16$ & $* * *$ \\
Taxon-biomass & 90 & 903.2 & 10.04 & 2.723 & $6.02 \mathrm{e}-09$ & $* * *$ \\
Sex-location & 6 & 41.1 & 6.85 & 1.858 & 0.09033 & Interaction insignificant \\
Residuals & $\mathbf{1 8 0}$ & $\mathbf{6 6 3 . 4}$ & $\mathbf{3 . 6 9}$ & & & \\
\hline
\end{tabular}

Levels of significance: ${ }^{*} p<0.01,{ }^{* * *} p<0.001$, interaction insignificant $(0.05 \leq p \leq 1)$ 
Table 5 List of willows analyzed in the heat map; abbreviations: 0-indeterminate sex, $\mathbf{F}-\mathbf{f e m a l e}, \mathbf{M}-$ male

\begin{tabular}{|c|c|c|c|c|c|c|c|c|}
\hline \multirow[t]{2}{*}{ No } & \multirow[t]{2}{*}{ Salix purpurea genotype name } & \multirow[t]{2}{*}{ Sex category } & \multicolumn{5}{|l|}{ Average } & \multirow[t]{2}{*}{ Group } \\
\hline & & & $\begin{array}{l}\text { Length of leaf } \\
\text { blade }(\mathrm{mm})\end{array}$ & $\begin{array}{l}\text { Width of leaf } \\
\text { blade (mm) }\end{array}$ & $\begin{array}{l}\text { Area of leaf } \\
\text { blade }\left(\mathrm{mm}^{2}\right)\end{array}$ & $\begin{array}{l}\text { Leaf elon- } \\
\text { gation }\end{array}$ & $\begin{array}{l}\text { Length of } \\
\text { petiole }(\mathrm{mm})\end{array}$ & \\
\hline 1 & '155/142' & 0 & 34 & 9 & 220 & 3.7 & 3.6 & 1 \\
\hline 2 & $7^{\prime}$ & $\mathrm{F}$ & 71 & 18 & 840 & 4.0 & 7.0 & 2 \\
\hline 3 & '16' & $\mathrm{F}$ & 84 & 18 & 1051 & 4.6 & 6.6 & 1 \\
\hline 4 & '23' & $\mathrm{F}$ & 76 & 15 & 717 & 5.2 & 3.4 & 1 \\
\hline 5 & ‘57' & $\mathrm{F}$ & 66 & 21 & 997 & 3.2 & 5.2 & 1 \\
\hline 6 & ‘58' & $\mathrm{F}$ & 85 & 15 & 878 & 5.7 & 5.6 & 1 \\
\hline 7 & '61' & $\mathrm{F}$ & 61 & 14 & 553 & 4.3 & 5.3 & 3 \\
\hline 8 & ‘63’ & $\mathrm{F}$ & 71 & 17 & 785 & 4.3 & 6.5 & 2 \\
\hline 9 & ‘69’ & $\mathrm{F}$ & 85 & 18 & 1083 & 4.8 & 5.9 & 2 \\
\hline 10 & $' 73$ ' & $\mathrm{F}$ & 69 & 14 & 713 & 4.8 & 6.1 & 3 \\
\hline 11 & $' 75 ’$ & $\mathrm{~F}$ & 70 & 16 & 840 & 4.4 & 5.0 & 3 \\
\hline 12 & ‘77' & $\mathrm{F}$ & 64 & 10 & 437 & 6.2 & 3.8 & 1 \\
\hline 13 & '79' & $\mathrm{F}$ & 69 & 15 & 721 & 4.5 & 6.6 & 3 \\
\hline 14 & '81' & $\mathrm{F}$ & 68 & 13 & 625 & 5.1 & 6.6 & 3 \\
\hline 15 & '82' & $\mathrm{F}$ & 68 & 15 & 672 & 4.6 & 5.9 & 3 \\
\hline 16 & '87' & $\mathrm{F}$ & 74 & 17 & 820 & 4.3 & 6.8 & 2 \\
\hline 17 & '126' & $\mathrm{F}$ & 74 & 19 & 956 & 3.9 & 4.3 & 2 \\
\hline 18 & ‘39/26’ & $\mathrm{F}$ & 83 & 18 & 1120 & 4.6 & 5.2 & 1 \\
\hline 19 & '149/136' & $\mathrm{F}$ & 39 & 9 & 228 & 4.4 & 3.1 & 1 \\
\hline 20 & '153/140' & $\mathrm{F}$ & 72 & 14 & 685 & 5.0 & 2.9 & 1 \\
\hline 21 & '156/143' & $\mathrm{F}$ & 58 & 14 & 538 & 4.1 & 6 & 3 \\
\hline 22 & '168/155' & $\mathrm{F}$ & 72 & 16 & 798 & 4.4 & 6.5 & 2 \\
\hline 23 & Scharfenbergiensis ' 76 ' & $\mathrm{F}$ & 91 & 19 & 1207 & 4.9 & 7.1 & 1 \\
\hline 24 & Helix Pyramidalis ' $160 / 147$ ' & $\mathrm{F}$ & 77 & 13 & 664 & 5.8 & 6.5 & 3 \\
\hline 25 & 'Angustifolia 68' & M & 82 & 15 & 818 & 5.6 & 7.5 & 3 \\
\hline 26 & 'Angustifolia 72' & M & 88 & 14 & 839 & 6.1 & 7.3 & 2 \\
\hline 27 & ‘66’ & M & 67 & 16 & 738 & 4.2 & 6.6 & 3 \\
\hline 28 & ‘67' & M & 94 & 16 & 908 & 6.0 & 8.1 & 3 \\
\hline 29 & '70’' & M & 70 & 17 & 820 & 4.2 & 7.5 & 2 \\
\hline 30 & $' 74 ’$ & M & 77 & 18 & 937 & 4.4 & 6.5 & 3 \\
\hline 31 & $' 78$ ' & M & 64 & 16 & 725 & 4.1 & 5.7 & 3 \\
\hline 32 & ‘84’ & M & 65 & 15 & 666 & 4.4 & 5.5 & 3 \\
\hline 33 & ' 125 ' & M & 82 & 14 & 733 & 5.7 & 6.4 & 1 \\
\hline 34 & '136/123' & M & 70 & 16 & 813 & 4.4 & 6 & 3 \\
\hline 35 & '151/138' & M & 92 & 21 & 1215 & 4.4 & 6.8 & 3 \\
\hline
\end{tabular}

conditions. Under worse conditions female individuals have higher survivability. This observation is similar to Tognetti (2012) conclusion that females are more common in highresource and males in low-resource microsites, but finally survivability is not the same as being more common.

Sex can indirectly affect plant growth, e.g., through the different preferences of herbivorous insects (Kabir et al. 2014) or roe deer (Moritz et al. 2018) for female and male specimens of willows. Therefore, drawing attention to willow sex seems to be essential, especially for owners of willow plantations. This was clearly indicated in this paper for $S$. purpurea, for which the shoot mass of male specimens was $31 \%$ greater than that of female specimens. This result, however, did not unambiguously confirm Harris and Pannell's (2008) thesis that females tend to be smaller than males in woody dioecious plant species because in the current investigation, the female specimens of other genotypes (Salix $\times$ rubra, S. $\times$ smithiana, $S$. fragilis) had a greater shoot mass than male specimens. This clearly indicates the need to correlate sex with the taxon. Especially, as in many scientific papers devoted to willow plantations this topic is often overlooked (Weih 


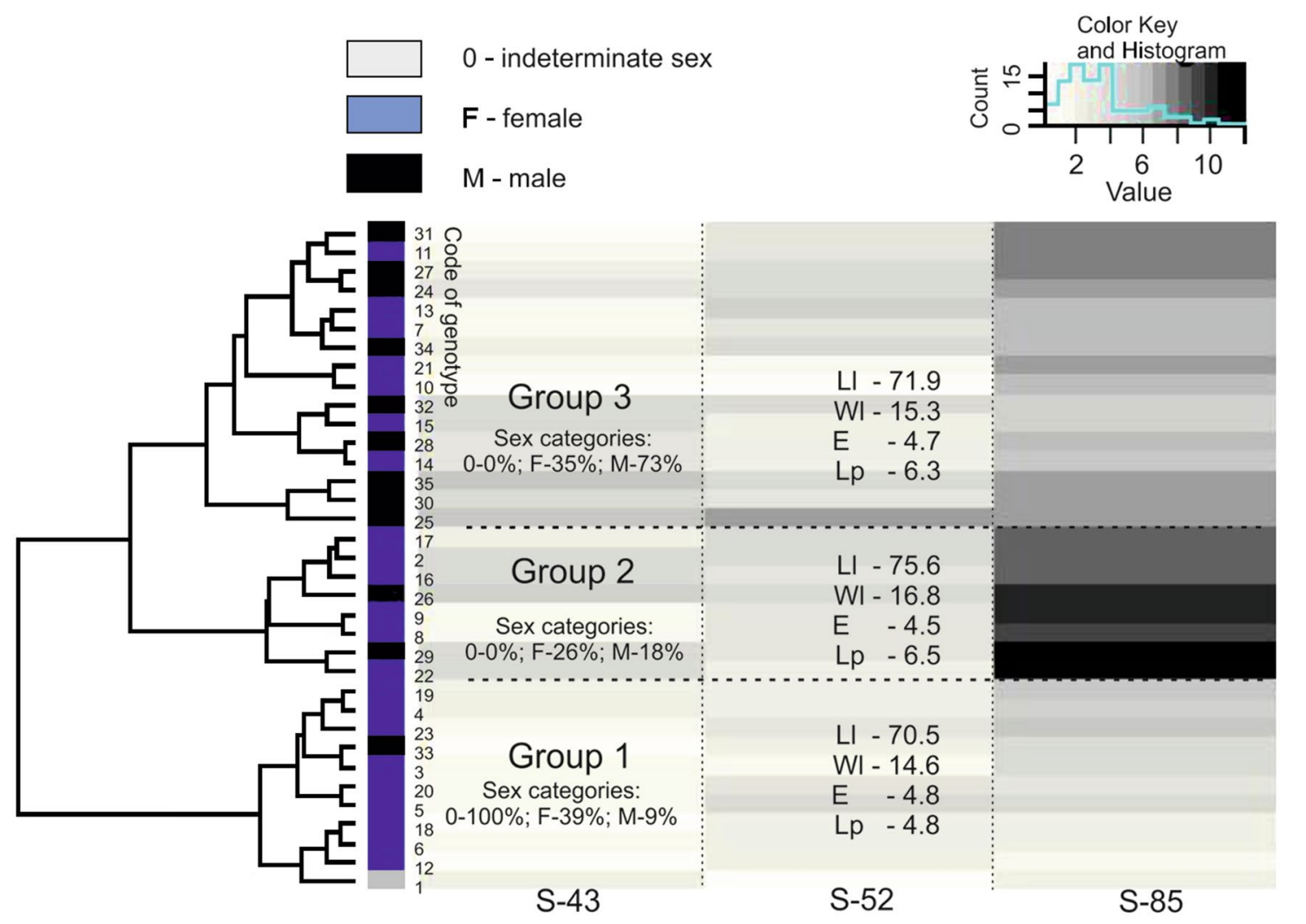

Fig. 10 Division into clusters in relation to the length of the leaf blade (Ll), leaf blade width (Wl), leaf slenderness (E) and petiole length (Lp)

Table 6 Differentiation of average length of leaf blade $(\mathrm{Ll})$, width of leaf blade (Wl), area of leaf blade $(\mathrm{Al})$, leaf elongation (E) and length of petiole (Lp) in three sex categories of Salix purpurea

\begin{tabular}{|c|c|c|c|c|c|c|}
\hline \multirow[t]{2}{*}{ Sex category } & \multirow{2}{*}{$\begin{array}{l}\text { No. of geno- } \\
\text { types }\end{array}$} & \multicolumn{5}{|c|}{ Average/SD } \\
\hline & & $\mathrm{Ll}(\mathrm{mm})$ & $\mathrm{Wl}(\mathrm{mm})$ & $\mathrm{Al}\left(\mathrm{mm}^{2}\right)$ & $\mathrm{E}$ & $\mathrm{Lp}(\mathrm{mm})$ \\
\hline 0 —-sex unknown & 1 & $34.0 /-$ & 9 & 220 & 3.7 & 3.6 \\
\hline 1 -females & 23 & $71.6 / 10.8$ & 15 & 785 & 4.6 & 5.5 \\
\hline 2 -males & 11 & $77.4 / 10.9$ & 16 & 823 & 4.9 & 6.7 \\
\hline
\end{tabular}

and Nordh 2005; Mitsui et al. 2010; Sevel et al. 2012; Aust et al. 2014; Han et al. 2020).

Leaf characteristics also reflected relationships with sex, as demonstrated on Hippophae rhamnoides (Li et al. 2007). The obtained results allow us to conclude that male specimens of $S$. purpurea have, on average, longer and wider leaves and thus a larger leaf area than female specimens. They also have much longer petioles. The smaller area of leaves in females can be associated with the energy that females have to expend in connection with the production of seeds. The correlation between this energy expenditure and leaf area is also indicated by the results obtained in this work showing that the smallest leaves and the shortest petioles were associated with willows of indeterminate sex, which may be a reflection of the relatively poor condition of these plants.
Differences between treatments in the biomass production of Corema album female individuals found by ÁlvarezCansino et al. (2010) confirmed the results of shoot elongation and supported the existence of a balance in resource investment between reproduction and maintenance of vegetative growth. Our study reveals a similar effect in the case of willows. There are still many questions associated with sexual dimorphism but we hope that the results described in this paper can help answer some of them.

\section{Conclusions}

Based on 8100 described and measured plants representing 150 genotypes of willows, including 8 species, 16 interspecies hybrids, cultivars and sex-differentiated specimens, we 
showed that: (1) males of the tested Salix genotypes had a higher biomass than females but the highest biomass yields were produced by bisexual specimens; (2) males of the tested willows showed a greater survival rate than females but only under better site conditions; when the site conditions were poorer, males had higher mortality rates than females; (3) hybrids had higher shoot biomass than the tested pure species; (4) for $S$. purpurea, which represented the largest number of genotypes in the study (46), male specimens had longer and wider leaves and thus a larger surface area on average than female specimens. They also had clearly longer petioles. The smallest leaves and the shortest petioles were associated with willows without catkins.

The results of this study indicate that in all works devoted to willows, both practical and scientific, it is necessary to refer not only to the willow species and environmental conditions in which they grow but also to the sex of the examined or cultivated individuals.

Acknowledgement This publication was financially supported by the framework of the Polish Ministry of Science and Higher Education program "Regional Initiative of Excellence" in 2019-2022, Project No. 005/RID/2018/19. The authors gratefully thank the staff of the LZD Siemianice and LZD Murowana Goślina and especially Mr. Roman Malik for help. Separate thanks go to the anonymous reviewers for their constructive criticism which has improved this work.

Author contributions PR, MM: conceptualization; formal analysis; investigation; visualization; roles/writing — original draft; writing-review and editing. MK: formal analysis; funding acquisition; resources; roles/writing — original draft; writing—review and editing. $\mathrm{AB}$ : data curation; visualization. KS: formal analysis; roles/writingoriginal draft. PG: funding acquisition; investigation; methodology; validation.

Funding The authors declare that they have no known competing financial interests or personal relationships that could have appeared to influence the work reported in this paper.

\section{Compliance with ethical standards}

Conflict of interest The authors declare that they have no conflict of interest.

Ethics approval and consent to participate This article does not contain any studies involving human participants or animals performed by any of the authors.

Open Access This article is licensed under a Creative Commons Attribution 4.0 International License, which permits use, sharing, adaptation, distribution and reproduction in any medium or format, as long as you give appropriate credit to the original author(s) and the source, provide a link to the Creative Commons licence, and indicate if changes were made. The images or other third party material in this article are included in the article's Creative Commons licence, unless indicated otherwise in a credit line to the material. If material is not included in the article's Creative Commons licence and your intended use is not permitted by statutory regulation or exceeds the permitted use, you will need to obtain permission directly from the copyright holder. To view a copy of this licence, visit http://creativecommons.org/licenses/by/4.0/.

\section{References}

Abouheif E, Fairbairn DJ (1997) A comparative analysis of allometry for sexual size dimorphism: assessing Rensch's rule. Am Nat 149:40-562

Álvarez-Cansino L, Zunzunegui M, Cruz Díaz Barradas M, Paz Esquivias M (2010) Gender-specific costs of reproduction on vegetative growth and physiological performance in the dioecious shrub Corema album. Ann Bot 106:989-998. https://doi. org/10.1093/aob/mcq197

Aust C, Schweier J, Brodbeck F, Sauter UH, Becker G, Schnitzler JP (2014) Land availability and potential biomass production with poplar and willow short rotation coppices in Germany. GCB Bioenergy 6:521-533. https://doi.org/10.1111/gcbb.12083

Bakšienè E, Titova J (2018) Effects of cultivation technologies on woody biomass yield of various willow (Salix spp.) cultivars. Zemdirbyste 105:339-348. https://doi.org/10.13080 /z-a.2018.105.043

Barrett SCH, Hough J (2013) Sexual dimorphism in flowering plants. J Exp Bot 64:67-82. https://doi.org/10.1093/jxb/ers308

Bhat GM, Islam MA, Malik AR, Rather TA, Sofi FM (2017) Willow industries in Kashmir valley: Present dynamics and future prospects. Rashtriya Krishi 12:79-83

Bierzychudek P, Eckhart V (1988) Spatial segregation of the sexes in dioecious plants. Am Nat 132:34-43

Colwell RK (2000) Rensch's rule crosses the line: convergent allometry of sexual size dimorphism in Hummingbirds and flower mites. Am Nat 156:495-510. https://doi.org/10.1086/303406

Dawson TE, Bliss LC (1989) Patterns of water use and the tissue water relations in the dioecious shrub, Salix arctica: the physiological basis for habitat partitioning between the sexes. Oecologia 79:332-343. https://doi.org/10.1007/bf00384312

Desborough MJR, Keeling DM (2017) The aspirin story-from willow to wonder drug. Br J Haematol 177:674-683. https://doi. org/10.1111/bjh. 14520

EC (2013) Interpretation manual of European Union habitats, vers. EUR28. Brussels: European Commission, DG Environment

Fairbairn DJ (1997) Allometry for sexual size dimorphism: patterns and process in the coevolution of body size in males and females. Annu Rev Ecol Syst 28:659-687. https://doi.org/10.1146/annur ev.ecolsys.28.1.659

Foellmer MW, Moya-Laraño J (2007) Sexual size dimorphism in spiders: patterns and processes. In: Fairbairn T, Blanckenhorn DJ, Székely WU (eds) Sex, size and sex roles. Oxford University Press, Oxford, Evolutionary studies of sexual size dimorphism, pp 71-81

Galambosi B, Galambosi Z, Uusitalo M, Heinonen A (2009) Effects of plant sex on the biomass production and secondary metabolites in roseroot (Rhodiola rosea L.) from the aspect of cultivation. J Med Spice Plant 14:114-121

Geber MA, Dawson TE, Delph LF (1999) Sex and sexual dimorphism in flowering plants. Springer, Berlin/Heidelberg

Geist V, Bayer M (2009) Sexual dimorphism in the Cervidae and its relation to habitat. J Zool 214:45-53. https://doi. org/10.1111/j.1469-7998.1988.tb04985.x

Goliński P, Rutkowski P, Waliszewska B, Stolarski M, Czapiewski G, Szentner K, Gąsecka M, Magdziak Z, Mleczek M (2015) Salix: properties and practical purposes in desmond, M.V. editor. Poplars 
and willows: cultivation, applications and environmental benefits. Nova Science Publishers, pp 29-73

Han Q, Harayama H, Uemura A, Ito E, Utsugi H, Kitao M, Maruyama Y (2020) High biomass productivity of short-rotation willow plantation in boreal Hokkaido achieved by mulching and cutback. Forests 11:505. https://doi.org/10.3390/f11050505

Harris MS, Pannell JR (2008) Roots, shoots and reproduction: sexual dimorphism in size and costs of reproductive allocation in an annual herb. Proc R Soc B Biol Sci 275:2595-2602. https://doi. org/10.1098/rspb.2008.0585

Hesse E, Pannell JR (2011) Sexual dimorphism in a dioecious population of the wind-pollinated herb Mercurialis annua: the interactive effects of resource availability and competition. Ann Bot 107:1039-1045. https://doi.org/10.1093/aob/mcr046

Hytönen J (1995) Ten-year biomass production and stand structure of Salix' aquatica' energy forest plantation in Southern Finland. Biomass Bioenergy 8:63-71. https://doi.org/10.1016/09619534(95)00003-P

Inkpen SA, Foellmer MW (2010) Sex-specific foraging behaviours and growth rates in juveniles contribute to the development of extreme sexual size dimorphism in a spider. Open Ecol $\mathrm{J}$ 3:59-70. https://doi.org/10.2174/1874213001003010059

Intha N, Chaiprasart P (2018) Sex determination in date palm (Phoenix dactylifera $\mathrm{L}$.) by PCR based marker analysis. Sci Hortic 236:251-255. https://doi.org/10.1016/j.scienta.2018.03.039

Juarez C, Banks JA (1998) Sex determination in plants. Curr Opin Plant Biol 1:68-72. https://doi.org/10.1016/S1369 $-5266(98) 80130-1$

Kabir F, Moritz KK, Stenberg JA (2014) Plant-sex-biased tritrophic interactions on dioecious willow. Ecosphere 5:1-9. https://doi. org/10.1890/ES14-00356.1

Labrecque M, Teodorescu TI (2003) High biomass yield achieved by Salix clones in SRIC following two 3-year coppice rotations on abandoned farmland in southern Quebec, Canada. Biomass Bioenerg 25:135-146. https://doi.org/10.1016/S0961 -9534(02)00192-7

Larsson S (1998) Genetic improvement of willow for short-rotation coppice. Biomass Bioenergy 15:23-26. https://doi.org/10.1016/ S0961-9534(98)80003-2

Li C, Xu G, Zang R, Korpelainen H, Berninger F (2007) Sex-related differences in leaf morphological and physiological responses of Hippophae rhamnoides along an altitudinal gradient. Tree Physiol 27:399-406. https://doi.org/10.1093/treephys/27.3.399

Lipiński AJ, Żejmo AA (2012) Cultivation of Salix viminalis willow and possibilities of improving the energy balance of eastern Poland voivodeships. Tech Sci 15:5-14

Lloyd DG, Webb CJ (1977) Secondary sex characters in plants. Bot Rev 43:177-216. https://doi.org/10.1007/BF02860717

Mercer CA, Eppley SM (2010) Intersexual competition in a dioecious grass. Oecologia 164:657-664. https://doi.org/10.1007/ s00442-010-1675-4

Mirski P (2014) Exceptions from dioecy and sex lability in genus Salix. Dendrobiology 71:167-171. https://doi.org/10.12657/ denbio.071.017

Mitsui Y, Seto S, Nishio M, Minato K, Ishizawa K, Satoh S (2010) Willow clones with high biomass yield in short rotation coppice in the southern region of Tohoku district (Japan). Biomass Bioenergy 34:467-473. https://doi.org/10.1016/j.biomb ioe. 2009.12 .010

Mleczek M, Rutkowski P, Goliński P, Szentner K, Waliszewska B, Stolarski M, Szczukowski S (2017) Biological diversity of Salix genotypes in $\mathrm{Cu}, \mathrm{Pb}$ and $\mathrm{Zn}$ phytoextraction from soil. Int J Phytoremediat 19:121-132. https://doi.org/10.1080/15226 514.2016.1207597
Mleczek M, Gąsecka M, Waliszewska B, Magdziak Z, Szostek M, Rutkowski P, Kaniuczak J, Zborowska M, Budzyńska S, Mleczek P, Niedzielski P (2018) Salix viminalis L. - A highly effective plant in phytoextraction of elements. Chemosphere 212:67-78. https://doi.org/10.1016/j.chemosphere.2018.08.055

Moritz KK, Parachnowitsch AL, Julkunen-Tiitto R, Bjorkman C, Ayres MP, Stenberg JA (2018) Roe deer prefer mixed-sex willow stands over monosexual stands but do not discriminate between male and female plants. Environ Exp Bot 146:62-67. https://doi.org/10.1016/j.envexpbot.2017.10.015

Nakahara T, Fukano Y, Hirota SK, Yahara T (2018) Size advantage for male function and size-dependent sex allocation in Ambrosia artemisiifolia, a wind-pollinated plant. Ecol Evol 8:1159-1170. https://doi.org/10.1002/ece3.3722

Nordh NE, Verwijst T (2004) Above-ground biomass assessments and first cutting cycle production in willow (Salix sp.) coppice-a comparison between destructive and non-destructive methods. Biomass Bioenergy 27:1-8. https://doi.org/10.1016/j. biombioe.2003.10.007

Obeso JR (2002) The costs of reproduction in plants. New Phytol 155:321-348

Ostaff DP, Mosseler A, Johns RC, Javorek S, Klymko J, Ascher JS (2015) Willows (Salix spp.) as pollen and nectar sources for sustaining fruit and berry pollinating insects. Can J Plant Sci 95:505-516. https://doi.org/10.4141/cjps-2014-339

Ott L (1984) An introduction to statistical methods and data analysis, 2nd edn. PWS Publishers, Boston

Owens IPF, Hartley IR (1998) Sexual dimorphism in birds: why are there so many different forms of dimorphism? Proc R Soc B Biol Sci 265:397-407. https://doi.org/10.1098/rspb.1998.0308

PN-ISO 10390 (1997) Jakość gleby-Oznaczanie pH. [Soil qualitydetermination of $\mathrm{pH}$ ]. Polski Komitet Normalizacyjny (Polish Committee for Standardization) (in Polish)

PN-ISO 11261 (2002) Jakość gleby-Oznaczanie azotu ogólnegoZmodyfikowana metoda Kjeldahla [Soil quality-Determination of total nitrogen-Modified Kjeldahl method]. Polski Komitet Normalizacyjny (Polish Committee for Standardization) (in Polish)

PN-ISO 14235 (2003) Jakość gleby-Oznaczanie zawartości węgla organicznego przez utlenianie dwuchromianem(VI) w środowisku kwasu siarkowego(VI) [Soil quality-Determination of organic carbon by sulfochromic oxidation]. Polski Komitet Normalizacyjny (Polish Committee for Standardization) (in Polish)

PN-R-04032 (1998) Gleby i utwory mineralne. Pobieranie próbek i oznaczanie składu granulometrycznego. [Soils and mineral soil materials. Samples collection and determination of granulometric composition] (in Polish)

PN-R-04033 (1998) Gleby i utwory mineralne. Podział na frakcje i grupy granulo- metryczne [Soils and mineral soil materials. Division into fraction and granulometric groups]. Polski Komitet Normalizacyjny (Polish Committee for Standardization) (in Polish)

Rensch B (1960) Evolution above species level. Columbia University Press, New York

Rutkowski P, Śliwa W, Kowal W (2007) Perspektywy hodowli drzewostanów dębowych w Nadleśnictwie Doświadczalnym Zielonka. In: Rutkowski P (ed) Hodowla dębów w Polsce. Wybrane zagadnienia, Sorus, Poznań, pp 135-144 (in Polish)

Rutkowski P, Goliński P, Konatowska M, Mleczek M, Szentner K, Waliszewska B, Maciejewska-Rutkowska I (2013) Wierzby (Salix) z kolekcji Uniwersytetu Przyrodniczego w Poznaniu [Willows (Salix) of Poznań University of Life Sciences Collection]. Wydawnictwo Uniwersytetu Przyrodniczego w Poznaniu, Poznań (in Polish) 
Sevel L, Nord-Larsen T, Raulund-Rasmussen K (2012) Biomass production of four willow clones grown as short rotation coppice on two soil types in Denmark. Biomass Bioenergy 46:664-672. https://doi.org/10.1016/j.biombioe.2012.06.030

Shea MM, Dixon PM, Sharitz R (1993) Size differences, sex ratio, and spatial distribution of male and female water tupelo, Nyssa aquatica (Nyssaceae). Am J Bot 80:26-30. https://doi. org/10.1002/j.1537-2197.1993.tb13763.x

Smart LB, Volk TA, Lin J, Kopp RF, Phillips IS, Cameron KD, White EH, Abrahamson LP (2005) Genetic improvement of shrub willow (Salix spp.) crops for bioenergy and environmental applications in the United States. Unasylva 221:51-55

Stace CA (1999) Field Flora of the British Isles. Edition (Abridged Ed) Publisher. Cambridge University Press, Cambridge

Tognetti R (2012) Adaptation to climate change of dioecious plants: does gender balance matter? Tree Physiol 32:1321-1324. https ://doi.org/10.1093/treephys/tps105
Uehleke B, Müller J, Stange R, Kelber O, Melzer J (2013) Willow bark extract STW 33-I in the long-term treatment of outpatients with rheumatic pain, mainly osteoarthritis or back pain. Phytomedicine 20:980984. https://doi.org/10.1016/j.phyme d.2013.03.023

Weih M, Nordh NE (2005) Determinants of biomass production in hybrid willows and prediction of field performance from pot studies. Tree Physiol 25:1197-1206. https://doi.org/10.1093/treep hys/25.9.1197

Yang G, Xu Q, Li W, Ling J, Li X, Yin T (2020) Sex-related differences in growth, herbivory, and defense of two Salix species. Forests 11:450. https://doi.org/10.3390/f11040450 